Article

\title{
High Performance Zinc Oxide Nanorod-Doped Ion Imprinted Polypyrrole for the Selective Electrosensing of Mercury II Ions
}

\author{
Zouhair Ait-Touchente ${ }^{1, *}$, Houssem Eddine El Yamine Sakhraoui ${ }^{2}\left(\mathbb{D}\right.$, Najla Fourati ${ }^{3, *} \mathbb{D}$, \\ Chouki Zerrouki ${ }^{3}$, Naima Maouche ${ }^{2}$, Nourdin Yaakoubi ${ }^{4}$, Rachid Touzani ${ }^{1}$ (D) and \\ Mohamed M. Chehimi ${ }^{5, *(D)}$ \\ 1 LCAE-FSO, Université Mohammed Premier, Oujda 60000, Morocco; r.touzani@ump.ac.ma \\ 2 Laboratoire d'Electrochimie et Matériaux, Université Ferhat Abbas, Sétif-1 19000, Algeria; \\ h_sakhraoui@hotmail.com (H.E.E.Y.S.); nmaouche@univ-setif.dz (N.M.) \\ 3 SATIE, UMR CNRS 8029, Cnam, 75003 Paris, France; zerrouki@cnam.fr \\ 4 LAUM, UMR CNRS 6613, Le Mans Université, 72085 Le Mans, France; nourdin.yaakoubi@univ-lemans.fr \\ 5 ICMPE, UMR CNRS 7182, CNRS, 94320 Thiais, France \\ * Correspondence: zouhair.aittouchente@gmail.com (Z.A.-T.); fourati@cnam.fr (N.F.); \\ chehimi@icmpe.cnrs.fr (M.M.C.); Tel.: +33-6-63-05-46-08 (M.M.C.)
}

Received: 3 September 2020; Accepted: 30 September 2020; Published: 8 October 2020

check for updates

\begin{abstract}
A biomimetic, ion-imprinted polymer (IIP) was prepared by electropolymerization of pyrrole at the surface of gold electrodes decorated with vertically grown $\mathrm{ZnO}$ nanorods. The vertical growth of the nanorods was achieved via an ultrathin aryl monolayer grafted by reduction of diazonium salt precursor. Pyrrole was polymerized in the presence of L-cysteine as chelating agent and $\mathrm{Hg}^{2+}$ (template). $\mathrm{Hg}^{2+}$-imprinted polypyrrole (PPy) was also prepared on a bare gold electrode in order to compare the two methods of sensor design (Au-ZnO-IIP vs. Au-IIP). Non-imprinted PPy was prepared in the same conditions but in the absence of any $\mathrm{Hg}^{2+}$ template. The strategy combining diazonium salt modification and $\mathrm{ZnO}$ nanorod decoration of gold electrodes permitted us to increase considerably the specific surface area and thus improve the sensor performance. The limit of detection (LOD) of the designed sensor was $\sim 1 \mathrm{pM}$, the lowest value ever reported in the literature for gold electrode sensors. The dissociation constants between PPy and $\mathrm{Hg}^{2+}$ were estimated at $\left[\mathrm{K}_{\mathrm{d} 1}=(7.89 \pm 3.63) \mathrm{mM}\right.$ and $\left.\mathrm{K}_{\mathrm{d} 2}=(38.10 \pm 9.22) \mathrm{pM}\right]$. The sensitivity of the designed sensor was found to be $0.692 \pm 0.034 \mu \mathrm{A} . \mathrm{pM}^{-1}$. The Au-ZnO-IIP was found to be highly selective towards $\mathrm{Hg}^{2+}$ compared to cadmium, lead and copper ions. This sensor design strategy could open up new horizons in monitoring toxic heavy metal ions in water and therefore contribute to enhancing environmental quality.
\end{abstract}

Keywords: ionic imprinted polypyrrole; zinc oxide nanorods; mercury ions; diazonium salts; electrochemical sensor

\section{Introduction}

One of the most serious problems affecting water is chemical pollution by organic or inorganic compounds such as pesticides and heavy metals, respectively. Among the inorganic pollutants, mercury (II) presents several health and ecosystem concerns [1-4]. Mercury is released into the environment in large quantities through waste from thermal power plants, cement kilns, chlor-alkali plants, gold mining and trash incinerators (hazardous waste, medical waste, regular garbage, etc.) [5-8]. Exposure to mercury ions, even at low doses, can lead to severe central nervous system problems and vital human organ damage [2,8-11]. The discharge of mercury into the environment is forbidden 
by the United States Environmental Protection Agency (USEPA), European Union (EU) and World Health Organization (WHO). The environmental monitoring of mercury is very much important to avoid any further damage to the ecosystem [12]. The WHO has set a maximum permissible limit of $\left(1 \mu \mathrm{g} \cdot \mathrm{L}^{-1} / 5 \mathrm{nM}\right)$ for mercury [13]. Developing reliable, sensitive and selective methods for the determination of mercury concentrations in food and drinking water is thus of particular significance.

Electrochemical sensors [4,14-17] are an excellent alternative combining miniaturization, speed and low cost. Field analysis of metal pollutants (even within a processing plant, for example) will be possible thanks to portable, wireless and ultra-sensitive potentiostats [18].

Ion imprinted polymers (IIPs) constitute a new class of sorbents possessing selectivity and affinity for the separation, pre-concentration or removal of target ions [14,16,19-21]. IIPs are prepared by the formation of specific recognition sites in the framework of organic polymers and usually prepared by the bulk polymerization method [16,22]. Template ions are then removed, leaving cavities or "artificial receptor sites" in the polymer layer that have appropriate shape, size and orientation of the functional groups for ion recognition at the rebinding stage [23-25]. For this reason, imprinted polymers are coined "plastic antibodies" for their ability to mimic antibodies. One of the most common applications of IIPs is solid phase extraction (SPE), which permits the pre-concentration of metal ions traces in environmental samples like natural water or seawater [26-28]. IIPs as electrochemical sensors have shown remarkable selectivity, good thermal stability, low cost and excellent sensitivity [29-34].

The current challenge for most scientific researchers is to improve the performance of electrochemical sensors, including the limit of detection, in order to detect heavy metal ions at trace levels and by using very simple and inexpensive methods. To address this issue, we reasoned to increase the electroactive surface using nanoparticles to form a nanostructured sensing layer [35,36].

Zinc oxide is considered to be a very important functional oxide among many semiconductor metal oxides [37] and, more generally, is one of the most used materials in applied sciences currently. It is a semiconductor; its wurtzite structure has a wide band gap $(\mathrm{Eg}=3.37 \mathrm{eV}$ at $300 \mathrm{~K})$ and a large exciton binding energy (60 meV) [38,39]; it has excellent biocompatibility, good chemical/thermal stability, mixed chemical bonds (covalent/ionic) [37], and it excellent properties allow it to be used in many applications as a nanomaterial, including in Gratzël cells [40], varistors [41], optical waveguides [42] and in many optoelectronic devices [38,43]. In addition to these applications, $\mathrm{ZnO}$ is widely used in the field of sensors, i.e., gas and heavy metal ion sensors [37,44-50].

$\mathrm{ZnO}$ thin films are prepared by many techniques such as chemical vapor deposition [51], spray pyrolysis [52], DC-sputtering [53], pulsed laser deposition [54], radiofrequency (RF) magnetron sputtering [55], pulsed laser deposition [56], electro-deposition [57] and sol-gel-dip-coating [58]. The low temperature chemical method [59-61] investigated herein is one of the most used techniques [47,53,59-61] for the preparation of thin films of $\mathrm{ZnO}$ due to its simplicity and operation at low temperatures. This method is carried out in three steps, (i): synthesis of ZnO NPs, (ii): deposition of NPs by spin-coating on gold electrodes, and (iii): growth of $\mathrm{ZnO} N R s$ ) and rests on the use of $\mathrm{ZnO} N P s$ as a seed layer to nucleate the growth process of $\mathrm{ZnO} N R$. This hydrothermal/chemical method is advantageous due to its low cost and the fact that it facilitates control over the density and overall orientation of nanorod arrays and permits control of the morphology of $\mathrm{ZnO}$ by varying the growth conditions such as growth time [61] and temperature [62].

In two recent conference proceedings $[63,64]$, we have proposed to combine the advantage of diazonium surface modification for the vertical growth of $\mathrm{ZnO}$ nanorods and sensing properties of polypyrrole. In this follow-up, we provide an in-depth study targeting the ultimate detection limit using $\mathrm{ZnO}$ nanorod-embedded ion imprinted polypyrrole. Besides the central role of diazonium modification of the working electrode for the growth of vertically aligned $\mathrm{ZnO}$ nanorods, such surface chemistry ensures robust adhesion of the polypyrrole sensing layer [65]. This strategy of gathering the salient features of diazonium salts, $\mathrm{ZnO}$ nanorods and ion imprinting of polypyrrole has never been reported before, with the exception of our short proceedings papers $[63,64]$. We believe it has much to 
offer to the surface scientist in the quest of constructing a robust electrochemical sensor to address environmental issues.

Herein, a polypyrrole-based IIP was prepared in the presence of $\mathrm{Hg}^{2+}$ as a template and L-cysteine as a chelatant agent deposited on a gold electrode sequentially functionalized with diazonium salts and nanostructured with $\mathrm{ZnO}$ nanorods in order to have very high roughness for the selective removal of mercury ions in a sample medium ( $\mathrm{KCl}$ solution). For comparison, an IIP on a bare gold electrode was prepared. A non-imprinted polymer was also prepared in the same conditions of IIP but in the absence of any $\mathrm{Hg}^{2+}$. Electropolymerization time, incubation time and number of cycles of electroreduction of diazonium salts were investigated and optimized. Electrode sensing materials were characterized by atomic force microscopy (AFM) in order to account for the morphological structures of the nanocomposites. Square wave voltammetry (SWV) experiments permitted us to determine the optimal parameters for sensing $\mathrm{Hg}^{2+}$, namely linear response range and the limit of detection of the $\mathrm{ZnO}$-IIP sensor. Selectivity and competition between mercury and other ions was investigated by examining the electrochemical responses in the presence of copper, lead and cadmium taken as interfering metal ions.

\section{Materials and Methods}

\subsection{Reagents}

First, 4-Aminobenzoic acid ( $\approx 99 \%)$, methanol $(\mathrm{MeOH}), \mathrm{H}_{2} \mathrm{SO}_{4}(95 \%), \mathrm{H}_{2} \mathrm{O}_{2} \quad(30 \%)$, tetrabutylammonium tetrafluoroborate $(99 \%)$, zinc acetate dihydrate $(99.99 \%)$, sodium hydroxide $(\approx 97 \%)$, hexamethylenetetramine $(99 \%)$, acetonitrile $(99.8 \%)$, potassium hexacyanoferrate(III) $(\approx 99 \%)$, potassium hexacyanoferrate(II) trihydrate $(\approx 98.5 \%)$, potassium chloride, pyrrole (Py) $(98 \%)$, lead nitrate $\mathrm{Pb}\left(\mathrm{NO}_{3}\right)_{2}$, copper(II) nitrate hemi(pentahydrate) $(98 \%)$ and mercury(II) chloride $(\approx 98 \%)$ were purchased from Sigma-Aldrich (Saint-Quentin-Fallavier, France). Pyrrole was purified through an alumina basic column and then stored in dark at $4{ }^{\circ} \mathrm{C}$. Cadmium sulfate $8 / 3$-hydrate $(\approx 99 \%)$ was supplied by VWR Prolabo (Fontenay-sous-Bois, France).

Zinc nitrate hexahydrate $(\approx 99 \%)$ was obtained from Merck (Fontenay-sous-Bois, France), and isopentyl nitrite ( $\approx 97 \%$ ) was supplied by Alfa Aesar (Heysham, UK). The organic solvents used were of analytical grade and all aqueous solutions were prepared using ultrapure milli-Q water.

\subsection{Instruments and Characterization}

All electrochemical measurements were carried out with a Bio-Logic portable potentiostat (model PG581). Conventional three-electrode cell was used. A silver chloride electrode (SSC, $+0.222 \mathrm{~V}$ vs. SHE), a platinum grid and a gold substrate were the reference, counter and working electrodes, respectively.

Topographical characterization was performed by atomic force microscopy (AFM, MFP-3 Asylum Research). X-ray photoelectron spectroscopy (XPS) analyses were conducted using a K Alpha apparatus (Thermo Fisher Scientific, East Grinsted, UK) fitted with an Al monochromatic X-ray source (1486.6 eV; spot size $=400 \mu \mathrm{m}$ ). A flood gun was used for charge compensation.

\subsection{Surface Functionalization with Diazonium Salt}

In order to mitigate the impurities likely to be present on the surface of the gold electrode and which can subsequently alter the quality of the surface modification, the gold substrates were cleaned with acetone in $10 \mathrm{~min}$ and then in a mixture of piranha $\left(98 \% \mathrm{H}_{2} \mathrm{SO}_{4} / 30 \% \mathrm{H}_{2} \mathrm{O}_{2} 2: 1 \mathrm{~V} / \mathrm{V}\right)$ for 20 and $10 \mathrm{~min}$ in ethanol. We then washed the gold electrodes thoroughly with distilled water and dried them at $60{ }^{\circ} \mathrm{C}$.

The surface modification was carried out by electrografting of 4-carboxybenzenediazonium-tetrafluoroborate (previously prepared [66] and characterized by FTIR and carbon-13 NMR) on gold electrodes by cyclic voltammetry at scan rate of $100 \mathrm{mV} / \mathrm{s}$ between -1.0 and $0.0 \mathrm{~V} / \mathrm{SSC}$ for 20 cycles, in acetonitrile solution, containing $1 \mathrm{mM}$ of diazonium salt and $0.1 \mathrm{M}$ of tetrabutylammonium 
tetrafluoroborate. The modified electrodes were then rinsed with ultrapure water and ethanol and dried. The number of cycles was optimized and controlled using ferrocyanide redox probe.

\subsection{Synthesis, Deposition and Vertical Growth of $\mathrm{ZnO}$}

The $\mathrm{ZnO}$ grafting procedure was performed in three steps by the low temperature method (Mekki et al. [47], Pacholski et al. [60]; Chander and Raychaudhuri [61]): (i) synthesis of ZnO nanoparticles from zinc acetate $[\mathrm{Zn}(\mathrm{CH} 3 \mathrm{COO}) 2]$ and sodium hydroxide $(\mathrm{NaOH})$, (ii) deposition of these nanoparticles on the surface and (iii) the vertical growth of the $\mathrm{ZnO}$ nanorods.

\subsubsection{Nanoparticle Synthesis}

Zinc acetate $\left[\mathrm{Zn}\left(\mathrm{CH}_{3} \mathrm{COO}\right)_{2} . \quad 2 \mathrm{H}_{2} \mathrm{O}\right]$ is among the most widely used precursors in several syntheses, including the synthesis of zinc oxide $(\mathrm{ZnO})$ nanoparticles [62,67]. In this work, $0.1 \mathrm{M}$ $\left[\mathrm{Zn}\left(\mathrm{CH}_{3} \mathrm{COO}\right)_{2} .2 \mathrm{H}_{2} \mathrm{O}\right]$ was reacted with $0.03 \mathrm{M}(\mathrm{NaOH})$ in methanol under stirring and heating at $60^{\circ} \mathrm{C}$. The various synthesis steps carried out are detailed below.

The first step corresponds to the dissolution of $\left[\mathrm{Zn}\left(\mathrm{CH}_{3} \mathrm{COO}\right)_{2} .2 \mathrm{H}_{2} \mathrm{O}\right]$ in methanol $\left(\mathrm{CH}_{3} \mathrm{OH}\right)$. Th second step is a chemical reaction between the species present in the solution to form the precipitation of metal hydroxide. The last step is the heat treatment to convert the zinc hydroxide particles to zinc oxide.

$$
\mathrm{Zn}\left(\mathrm{CH}_{3} \mathrm{COO}\right)_{2}+\mathrm{CH}_{3}-\mathrm{CH}_{2}-\mathrm{OH} \rightarrow \mathrm{Zn}^{2+}+2 \mathrm{CH}_{3} \mathrm{COO}^{-}
$$

The sodium hydroxide dissolves in the solution to give $\mathrm{Na}^{+}$, which will bind to the acetate; the $\mathrm{OH}^{-}$group will precipitate with the $\mathrm{Zn}^{2+}$ which is in the solution, before obtaining the zinc monoxide, which has a white color.

$$
\begin{gathered}
\mathrm{Zn}^{2+}+2 \mathrm{OH}^{-} \rightarrow \mathrm{Zn}(\mathrm{OH})_{2} \downarrow \\
\mathrm{Zn}(\mathrm{OH})_{2} \rightarrow \mathrm{ZnO}+\mathrm{H}_{2} \mathrm{O}
\end{gathered}
$$

\subsubsection{Deposition of $\mathrm{ZnO}$ Nanoparticles on Aryl-Modified Gold Electrodes}

After synthesis, $\mathrm{ZnO}$ nanoparticles were deposited on the modified gold electrode (Au-diazo) by spin-coating to serve as a germination layer for the nucleation process during the growth of $\mathrm{ZnO}$ nanorods. These electrodes were dried in the oven at $125^{\circ} \mathrm{C}$ for one hour before proceeding to the growth step.

\subsubsection{Vertical Growth of $\mathrm{ZnO}$ Nanorods}

For the nanorod growth step, the $\mathrm{ZnO}$ NP-coated arylated gold substrates were immersed in a beaker containing a $30 \mathrm{mM}$ solution of the zinc nitrate hexahydrate $\left[\mathrm{Zn}\left(\mathrm{NO}_{3}\right)_{2} \cdot 6 \mathrm{H}_{2} \mathrm{O}\right]$ and $30 \mathrm{mM}$ hexamethylenetetramine (HMT) dissolved in $200 \mathrm{~mL}$ of distilled water; the mixture was kept at $95^{\circ} \mathrm{C}$ for $5 \mathrm{~h}$ with constant stirring. Since the particles act as a nucleation site, after the five hours of growth, the samples were removed from solution, rinsed with distilled water and dried (for $1 \mathrm{~h}$ at $125^{\circ} \mathrm{C}$ ).

\subsection{Preparation of $A u-I I P, A u-Z n O-I I P$ and $A u-Z n O-N I P$}

Two different IIPs were prepared. The first one was made on a bare gold electrode and the second one was prepared on a gold electrode modified with diazonium salt and $\mathrm{ZnO}$ nanorods. These two configurations were carried out in two steps; for the first, a thin PPy barrier layer was deposited by chronoamperometry for $2 \mathrm{~s}$ at an applied potential of $1.05 \mathrm{~V}(\mathrm{vs} \mathrm{Ag} / \mathrm{AgCl}$ ) in a $\mathrm{KCl}$ solution containing $10^{-2} \mathrm{M}$ of purified pyrrole (monomer) and $10^{-4} \mathrm{M}$ of L-cysteine; the second step involved $8 \mathrm{~s}$ in a $\mathrm{KCl}$ solution containing $10^{-2} \mathrm{M}$ of purified pyrrole, $10^{-4} \mathrm{M}$ of L-cysteine and $10^{-3} \mathrm{M}$ of $\mathrm{Hg}^{2+}$ (template). These different steps were carried out by chronoamperometry at an applied potential of 
$1.05 \mathrm{~V}$ (vs. $\mathrm{Ag} / \mathrm{AgCl})$. The non-imprinted polymer (Au-ZnO-NIP) was also prepared under the same conditions in the absence of any $\mathrm{Hg}^{2+}$ ion template.

\subsection{Choice and Role of the Chelating Agent}

The formation of mercury receptor sites in the ZnO-IIP was achieved using L-cysteine, a chelator of mercury. This choice was driven by the thiophilicity of metal ions [68-70] and especially high affinity of L-Cys for $\mathrm{Hg}^{2+}$ [71]. L-cysteine is an ideal compound, bearing electron-rich functional groups such as $-\mathrm{NH}_{2},-\mathrm{COOH}$ and $-\mathrm{SH}$, which allow it to have a Hg-cysteine complex [72-74]. The incorporation of $\mathrm{L}$-cysteine/ $\mathrm{Hg}^{2+}$ into polypyrrole is likely to take place via electrostatic bonds between the carboxylic group of L-cys and the nitrogen of pyrrole (Scheme 1) [74].

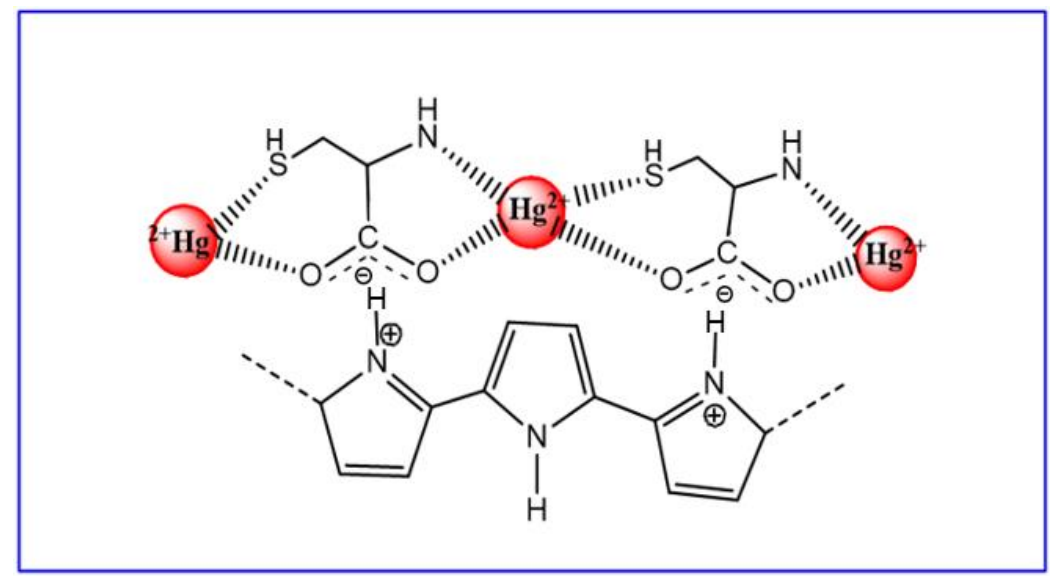

Scheme 1. Schematic representation of $\mathrm{Hg}^{2+}$ complexation by L-cysteine in the polypyrrole layer.

\subsection{Electrochemical Measurements}

The comparison between the prepared configurations, the $\mathrm{Hg}^{2+}$ detection tests, selectivity, competition between $\mathrm{Hg}^{2+}$ and other ions was controlled by square wave voltammetry between -0.95 and $0.95 \mathrm{~V}$ under the following conditions: E-pulse: $0.01 \mathrm{~V}$, E-step: $0.01 \mathrm{~V}$, frequency: $25 \mathrm{~Hz}$, equilibration time: $2 \mathrm{~s}$. After each use, the IIP was extracted for $20 \mathrm{~min}$ in EDTA and then $10 \mathrm{~min}$ in ultra-pure water with gentle stirring. Once the IIP was extracted, it could be used another time.

\section{Results and Discussion}

\subsection{Surface Functionalization by 4-Carboxybenzenediazonium Tetrafluoroborate and Quasi-Vertical Growth of $\mathrm{ZnO}$}

Scheme 2 displays the general three-step design of IIPs. To do so, we functionalized the surface of the gold electrode with carboxyphenyl groups from the corresponding diazonium salt (Scheme 2A, (1)) and then deposited (by spin-coating) $\mathrm{ZnO}$ nanoparticles for the vertical growth of the $\mathrm{ZnO}$ nanorods (Scheme 2A, (2)). The second step consisted of the formation of the ion-imprinted polypyrrole by electropolymerization of the pyrrole in the presence of L-cysteine (chelator) and $\mathrm{Hg}^{2+}$ template (Scheme 2B).

The different steps followed for the formation of ionic cavities are illustrated in Scheme 2C [75]. Removal of the template by washing, adapted to the nature of the functional monomer-template bond, leaves artificial sites capable of selective rebinding of the template. 


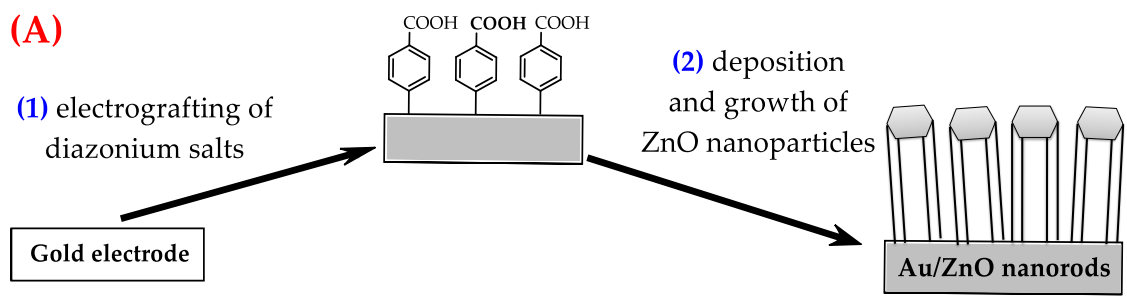

(B)

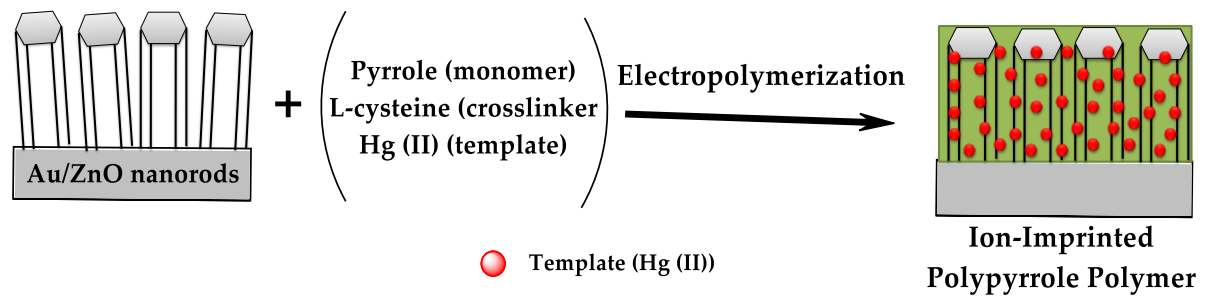

(C)
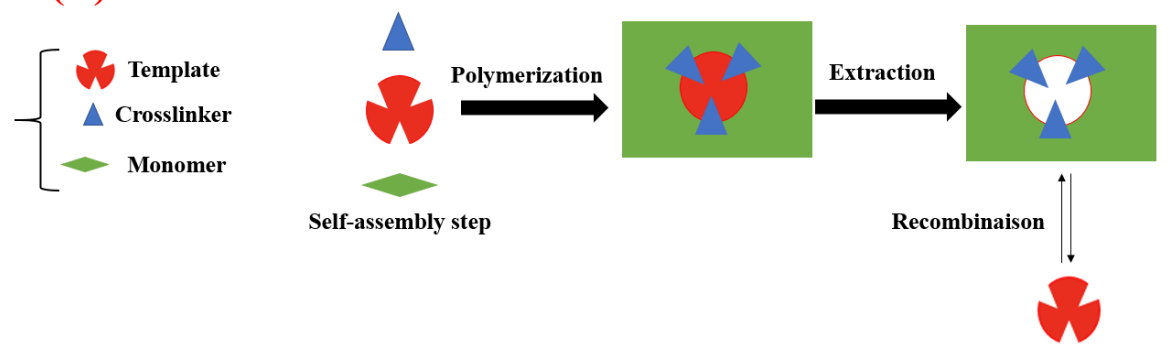

Scheme 2. Schematic illustration of experimental procedures. (A): Design of $\mathrm{ZnO}$ nanorods, (B): design of the ion imprinted polymer and (C): principle of formation of an artificial receptor within a polymer matrix for hosting metal ion template at the rebinding step.

The electroreduction of the diazonium salt carried out by cyclic voltammetry in 20 cycles in the range -1.0 to $0.0 \mathrm{~V}$ (vs. $\mathrm{Ag} / \mathrm{AgCl}$ ) gave a virtually zero reduction current (Figure $1 \mathrm{~A}$ ) resulting from a passivation of the electrode following the grafting of diazonium groups (formation of gold-diazo covalent bonds). The electroreduction peak is centered at $-0.2 \mathrm{~V}$ (vs. $\mathrm{Ag} / \mathrm{AgCl}$ ). This step of surface functionalization by the diazonium salt makes it possible to tether ZnO NPs to the surface on the one hand and enables vertical growth of $\mathrm{ZnO} N R s$ on the other hand. We have shown in a previous work that the growth of $\mathrm{ZnO}$ NRs on a surface not modified by diazonium salts gives an orientation of the NRs in all directions and in a random manner [47].
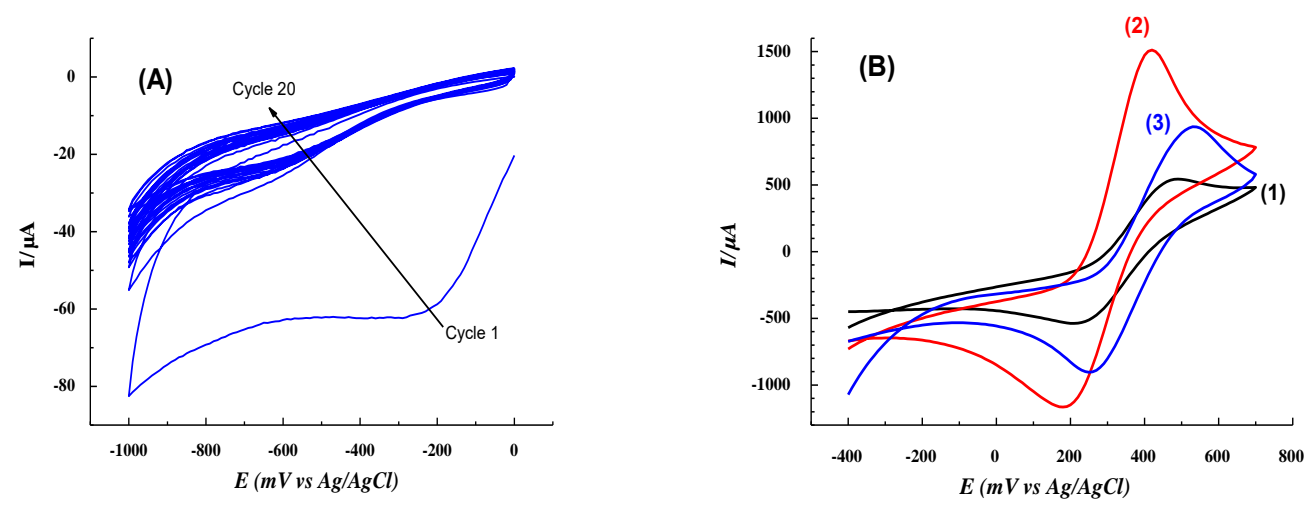

Figure 1. Cyclic voltammograms corresponding to the electrografting of 4-carboxybenzenediazonium tetrafluoroborate. (A) Electroreduction, (B) passivation test in $\mathrm{H}_{2} \mathrm{O} / \mathrm{KCl} 0.1 \mathrm{M}$ solution, containing $0.01 \mathrm{M}$ of $\mathrm{K}_{3}\left[\mathrm{Fe}(\mathrm{CN})_{6}\right]$ and $0.01 \mathrm{M}$ of $\mathrm{K}_{4}\left[\mathrm{Fe}(\mathrm{CN})_{6}\right]$ : (1): as-received gold electrode; (2): cleaned electrode and (3): after electrografting of the diazonium salt. Scan rate: $100 \mathrm{mV} / \mathrm{s}, 20$ cycles for electrografting. 
Passivation of the electrode was followed by cyclic voltammetry in the presence of $0.01 \mathrm{M}$ of

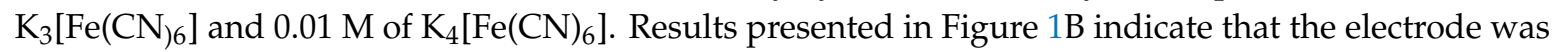
passivated while keeping its conductive character (Figure 1B, red). The diazonium salt step makes it possible to achieve an almost homogeneous distribution of quasi-vertical growth of $\mathrm{ZnO}$ nanorods [47].

\subsection{Preparation of IIP and NIP-Based Electrodes}

Mercury oxidation on gold electrodes yields two peaks: the first peak is attributed to the oxidation reaction of $\mathrm{Hg}(0)$ to $\mathrm{Hg}(\mathrm{I})$ (in the form $\mathrm{Hg}_{2}{ }^{2+}$ ) while the second peak is due to the transformation of $\mathrm{Hg}(\mathrm{I})$ into $\mathrm{Hg}^{2+}[68,76,77]$ :

$$
1 / 2 \mathrm{Hg}_{2}{ }^{2+} \rightarrow \mathrm{Hg}^{2+}+\mathrm{e}^{-}\left(\text {or } \mathrm{Hg}(\mathrm{I}) \rightarrow \mathrm{Hg}(\mathrm{II})+\mathrm{e}^{-}\right)
$$

Before preparing the films on gold electrodes, we first characterized the signature of mercury with a gold disk working electrode in a solution containing mercury and $\mathrm{KCl} 0.1 \mathrm{M}$. The response obtained by SWV shows that the oxidation of mercury on gold gives two peaks at 0.061 and $0.71 \mathrm{~V}(\mathrm{vs} . \mathrm{Ag} / \mathrm{AgCl})$ (Figure 2). The position of the two peaks depends on the $\mathrm{pH}$ of the solution, the nature of the working electrode, the electrolyte and the layer or film deposited on gold. In the following, we will consider the most intense peak located at $0.71 \mathrm{~V}$ (vs. $\mathrm{Ag} / \mathrm{AgCl}$ ), which corresponds to $\mathrm{Hg}^{2+}$. This dominant peak means that most of the mercury is converted to $\mathrm{Hg}^{2+}$.

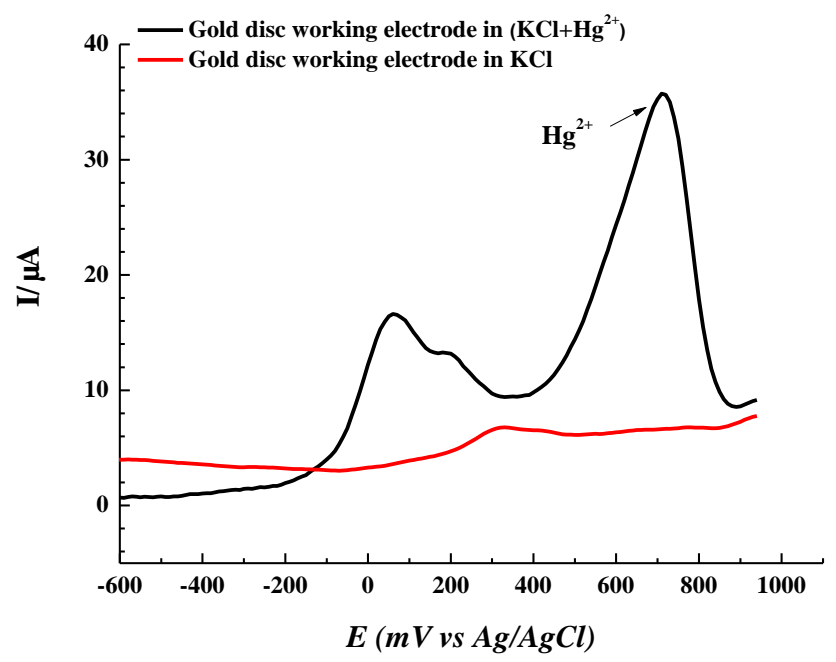

Figure 2. Characteristic peaks of mercury oxidation on gold electrode in $\mathrm{H}_{2} \mathrm{O} / \mathrm{KCl} 0.1 \mathrm{M}$ solution. Conditions: E-pulse: $0.01 \mathrm{~V}$, E-step: $0.01 \mathrm{~V}$, frequency: $25 \mathrm{~Hz}$, equilibration time: $2 \mathrm{~s}$.

A thin PPy barrier layer was deposited by chronoamperometry (CA) for $2 \mathrm{~s}$ before Au-ZnO-IIP electro-formation to prevent the complexation of mercury by Au-ZnO electrodes (Figure 3A, black curve). Both $\mathrm{ZnO}-\mathrm{IIP}$ and $\mathrm{ZnO}-\mathrm{NIP}$ were prepared by the same technique (Figure 3A, red curve) and then compared using SWV (Figure 3B). On the one hand, one can notice the obvious difference between the responses of $\mathrm{ZnO}-\mathrm{IIP}$ and $\mathrm{ZnO}-\mathrm{NIP}$, i.e., mainly for the peak current corresponding to a potential of around $0.62 \mathrm{~V}$ (vs. $\mathrm{Ag} / \mathrm{AgCl}$ ) in the case of $\mathrm{ZnO}-\mathrm{IIP}$ will be considered for quantitative monitoring of mercury. On the other hand, the removal of $\mathrm{Hg}^{2+}$ from $\mathrm{ZnO}-\mathrm{IIP}$ by EDTA leads to a flat SWV response, close to that of $\mathrm{ZnO}-\mathrm{NIP}$ (Figure 3B). This means that all receptor sites have been released and thus can be reused for rebinding the target ions. 

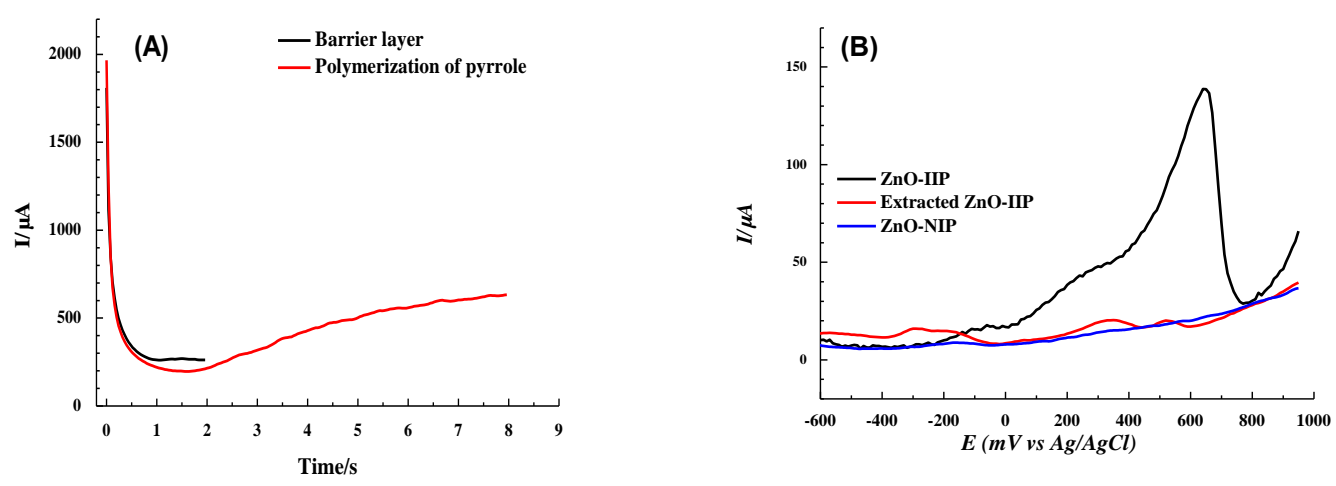

Figure 3. (A): Electropolymerization of pyrrole by chronoamperometry at a constant potential of 1.05 V/SSC. (black) Barrier layer, (red) Polymerization of pyrrole in the presence of L-cysteine and $\mathrm{Hg}^{2+}$

(B): square wave voltammetry (SWV) of IIP and NIP in $\mathrm{H}_{2} \mathrm{O} / \mathrm{KCl} 0.1 \mathrm{M}$ solution.

In order to showcase the central role of $\mathrm{ZnO}$ nanorods, we prepared two different IIPs: the first was prepared directly on a bare gold electrode and the second IIP was prepared on $\mathrm{Au}-\mathrm{ZnO}$. After extraction of the metal ions from these two IIPs in EDTA solution, they were incubated in $10^{-3} \mathrm{M}$ mercury solution for $20 \mathrm{~min}$ for the rebinding test.

From the results displayed in Figure 4, one can notice the important role of $\mathrm{ZnO}$ NRs thanks to the spaces between the NRs. ZnO NRs will be considered as a substrate for depositing the polymer matrix instead of depositing it directly on the gold electrode.

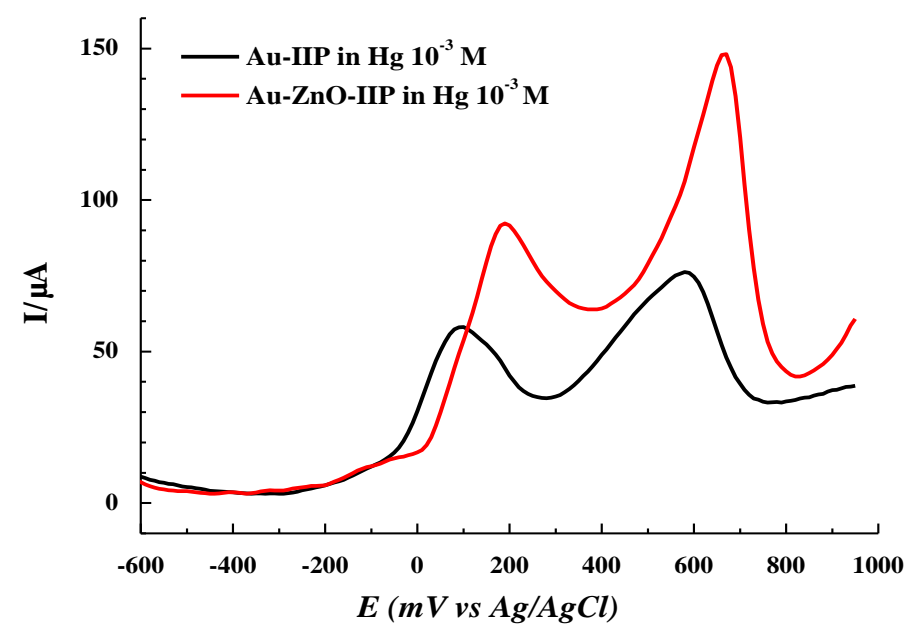

Figure 4. SWV voltammograms in $\mathrm{H}_{2} \mathrm{O} / \mathrm{KCl} 0.1 \mathrm{M}$ solution after incubation of $\mathrm{Au} / \mathrm{Hg}-\mathrm{IIP}$ and Au-ZnO/Hg-IIP in $10^{-3} \mathrm{M} \mathrm{Hg}^{2+}$. Conditions: E-pulse: $0.01 \mathrm{~V}$, E-step: $0.01 \mathrm{~V}$, frequency: $25 \mathrm{~Hz}$, equilibration time: $2 \mathrm{~s}$.

Square wave voltammograms presented in Figure 4 show that the current intensity of the IIP prepared on $\mathrm{ZnO}$ nanorods is twice as high as that prepared on bare gold electrodes. Given that the surface area used on the bare gold electrode to form $\mathrm{Au} / \mathrm{Hg}$-IIP is identical to that used to form $\mathrm{Au}-\mathrm{ZnO} / \mathrm{Hg}$-IIP, this can be related to the increase in the surface area thanks to $\mathrm{ZnO}$ nanorods, which makes it possible to deposit more IIP and thus a large number of artificial sites to capture more $\mathrm{Hg}^{2+}$ ions.

\subsection{Surface Analysis by XPS}

Figure 5 shows the survey spectra for the bare gold electrode, $\mathrm{Au} /$ diazo- $\mathrm{COOH}, \mathrm{Au}-$ diazo- $\mathrm{ZnO}$ nanoparticles, Au-diazo-ZnO nanorods, $\mathrm{ZnO}-\mathrm{IIP}$ and $\mathrm{ZnO}-\mathrm{NIP}$. 


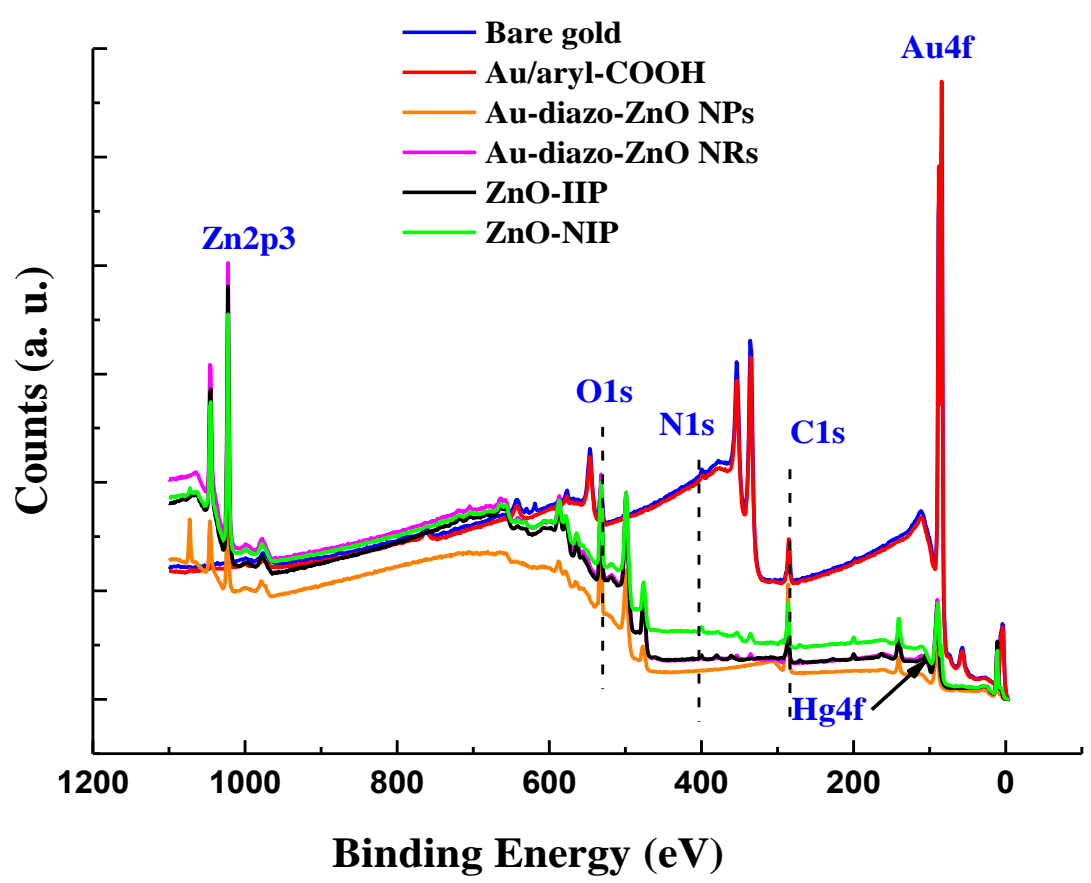

Figure 5. XPS survey scans of $\mathrm{Au}$ electrode, $\mathrm{Au} /$ diazo-COOH, Au-diazo-ZnO nanoparticles, Au-diazo-ZnO nanorods, $\mathrm{ZnO}-\mathrm{IIP}$ and $\mathrm{ZnO}-\mathrm{NIP}$.

Firstly, comparison of the XPS spectrum of bare gold electrode with Au/diazo-COOH confirms the effective reductive electrografting reaction of the diazonium salt on the gold electrode. Indeed, it is noticed the presence of characteristic signals of the diazo- $\mathrm{COOH}$, namely $\mathrm{C} 1 \mathrm{~s}$ and $\mathrm{N} 1 \mathrm{~s}$ peaks centered at $285 \mathrm{eV}$ and $400 \mathrm{eV}$, respectively (Figure 5). It should be noted that the surface-grafted layer seems to be relatively thin (less than $10 \mathrm{~nm}$ ); this was also confirmed by the atomic percentages shown in Table 1 . The atomic percentage of gold decreased from $41.6 \%$ for the bare gold electrode to $35.8 \%$ after electrografting of the diazonium salt, with a small increase in the percentage of carbon (grafting of the diazonium salt while keeping the conductive activity of the electrode).

Table 1. Surface chemical composition of Au electrode, $\mathrm{Au} /$ diazo- $\mathrm{COOH}, \mathrm{Au}$-diazo-ZnO nanoparticles, Au-diazo-ZnO nanorods, $\mathrm{ZnO}-\mathrm{IIP}$ and $\mathrm{ZnO}-\mathrm{NIP}$ nanocomposites as determined by XPS.

\begin{tabular}{ccccccc}
\hline Samples & $\mathbf{A u}$ & $\mathbf{C}$ & $\mathbf{O}$ & $\mathbf{N}$ & $\mathbf{Z n}$ & $\mathbf{H g}$ \\
\hline Bare gold electrode & 41.6 & 42.2 & 16.2 & - & - & - \\
\hline $\mathrm{Au}$ /diazo-COOH & 35.8 & 45.9 & 14.3 & 3.97 & - & - \\
\hline Au-diazo-ZnO NPs & - & 60.6 & 28.3 & 0.43 & 10.7 & - \\
\hline Au-diazo-ZnO NRs & 0.87 & 32.3 & 38.5 & 0.97 & 27.4 & - \\
\hline ZnO-IIP & 0.07 & 43.0 & 33.2 & 2.38 & 20.7 & 0.57 \\
\hline ZnO-NIP & 1.61 & 43.5 & 33.3 & 2.95 & 18.7 & - \\
\hline
\end{tabular}

After the deposition of $\mathrm{ZnO}$ nanoparticles by spin-coating, we have the appearance of a peak at $1022 \mathrm{eV}$ which corresponds to the $\mathrm{Zn} 2 \mathrm{p}_{3 / 2}$ of $\mathrm{ZnO}$ (Figure 5), with an atomic percentage of $10.7 \%$. After the $\mathrm{ZnO}$ growth step, the atomic percentages of zinc and oxygen increase ( $27.4 \%$ and $38.5 \%$, respectively). We can also note a decrease in the peaks corresponding to the $A u 4 f_{7 / 2}$ and $\mathrm{C} 1 \mathrm{~s}$ signals (Figure 5), which confirms the success of the $\mathrm{ZnO}$ nanorods growth step.

Comparison of the XPS spectra of ZnO-IIP and ZnO-NIP (Figure 5) indicates the grafting of a polypyrrole film on the surface of the electrode. However, mercury is present only in the case of the IIP 
material, which indicates that the template has been well trapped in the polymeric matrix. The atomic percentage of $\mathrm{Zn}$ for NIP and IIP decreased due to screening $\mathrm{ZnO}$ with polypyrrole (Table 1).

As per the thickness of the aryl layer, it was determined using the Beer-Lambert exponential decay of the intensity of bare gold:

$$
I=I^{\circ} \exp (-d / \lambda \cos \theta)
$$

where $I$ is the peak intensity of Au4f $\mathrm{f}_{7 / 2}$ core level signal after coating, $I^{\circ}$ is the intensity for the bare gold, $d$ is the aryl thickness, $\lambda$ the mean free path of Au4f $\mathrm{f}_{7 / 2}$ in the aryl layer and $\theta$ the analysis angle (here, $\theta=0$, and $\cos \theta=1$ ). The thickness is estimated to be $0.43 \mathrm{~nm}$ by considering $\lambda$ to be around $4.1 \mathrm{~nm}$, which, for a monolayer of aryl groups given the fact that the size of length of benzoic acid, is around $0.49 \mathrm{~nm}$.

As will be shown below by AFM, ZnO NPs are large compared to the sampling depth ( 2-10 $\mathrm{nm})$ in XPS. For this reason, no gold is detected for Au-diazo-ZnO NPs. After growth of the NRs, Au4f doublet is detected again, which signifies that deposition of the NRs probably induces partial leaching of $\mathrm{ZnO}$ NPs, hence the escape of Au4f electrons between the NRs and their detection in XPS.

\subsection{Topographical Characterization}

The atomic force microscopy (AFM) measurements have been carried out in order to monitor the topographic changes after each surface functionalization step. The evidence of nanorod growth is not the purpose herein, that being clearly shown in a previous work [47]. Therefore, we can use standard tapping mode AFM probes instead of high aspect ratio ones. The robustness of the former allows comparative investigation of several samples' surfaces without changing the probe. Two-dimensional AFM images of $(5 \times 5) \mu \mathrm{m}^{2}$ have thus been achieved on the same sample, before (bare gold substrate) and after each functionalization step (diazonium salt, $\mathrm{ZnO}$ nanoparticles, $\mathrm{ZnO}$ nanorods, then IIP) and finally after extraction of the $\mathrm{Hg}^{2+}$ template (Figure 6).
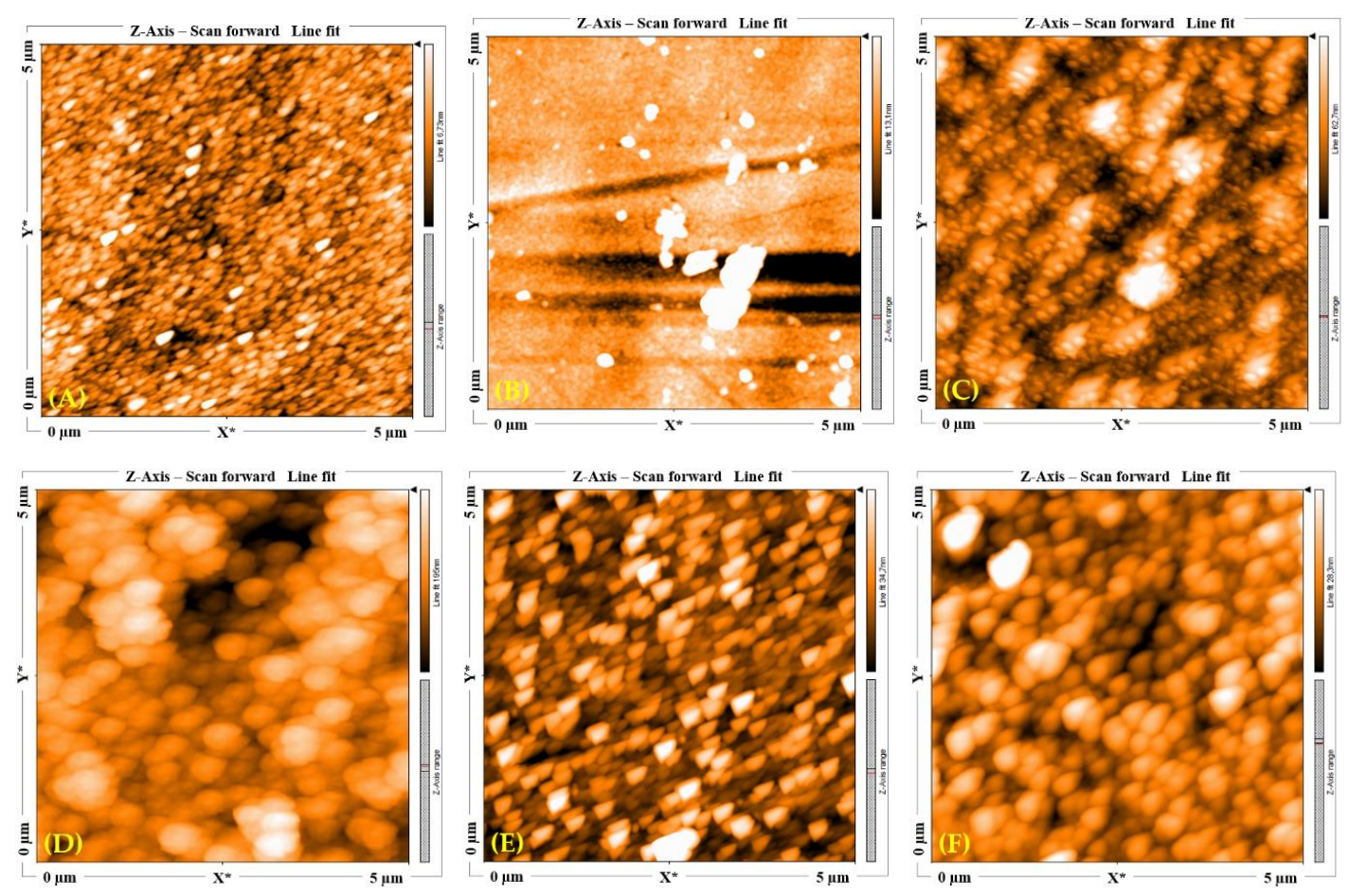

Figure 6. The generated $5 \times 5 \mu \mathrm{m}^{2}$ AFM images of (A) bare gold electrode, (B) gold electrode-diazonium salt, (C) Au/Diazo/ZnO nanoparticles, (D) Au/Diazo/ZnO nanorods, (E) Au/Diazo/ZnO NRs-IIP, (F) extracted $\mathrm{Au} / \mathrm{Diazo} / \mathrm{ZnO}$ NRs-IIP. 
The AFM images (Figure 6A-F) exhibit a granular-like aspect and seem different enough in both shape and size. The grafting of diazonium salt (Figure 6B) leads to the formation of a layer veiling the granular appearance. The latter is again visible (Figure $6 \mathrm{C}$ ) after grafting the $\mathrm{ZnO}$ nanoparticles, with higher contrast than for the bare gold surface (Figure 6A). Figure 6D, which corresponds to $\mathrm{ZnO}$ nanorod growth, exhibits the largest size of surface singularities, which seems reduced by the electropolymerization of IIP (Figure 6E). The extraction of template from the IIP film (Figure 6F) leads to a different aspect that is probably due to the local rearrangement of the IIP.

Despite the usefulness of AFM images, qualitative description remains limited due to the high contrast that may exist in the presence of multiple defects with high amplitudes. Measurements should therefore be considered from a quantitative point of view by considering relevant roughness statistical parameters, such as rms roughness $(S q)$ and peak-valley height $(S p-S v)$. Values of these two parameters are presented in Figure 7.
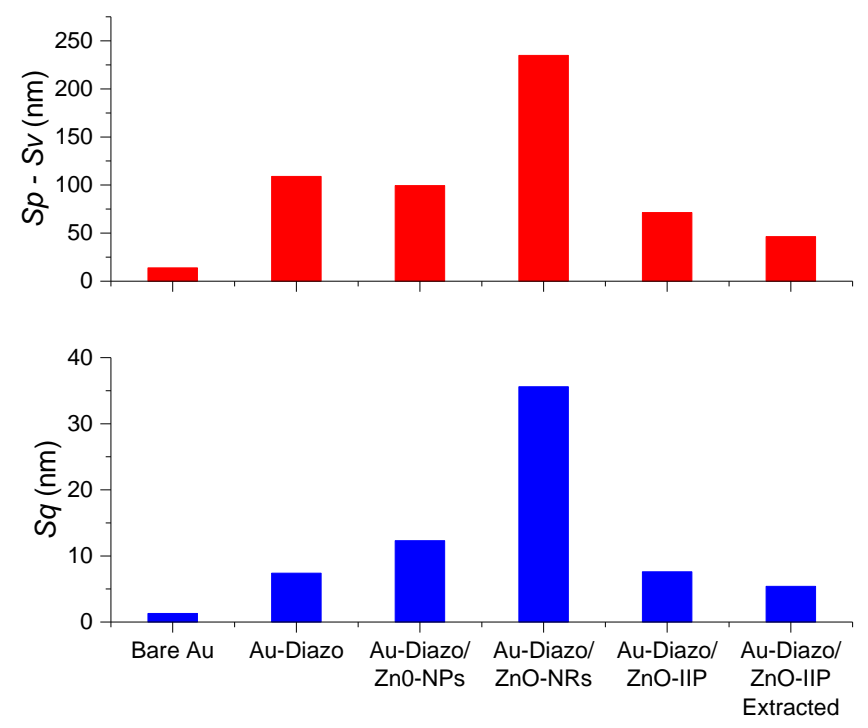

Figure 7. Root-mean-square height $(S q)$ and peak-valley height $(S p-S v)$ values after the different functionalization steps, from bare gold substrate to electrosynthesis of IIP and the further extraction of the imprinted $\mathrm{Hg}^{2+}$ template ions.

As expected, each surface modification leads to a noticeable change in roughness parameters. The most important one occurs after diazonium salt grafting. This first step of functionalization led to an increase in $(S q)$ and $(S p-S v)$ parameter values by a factor of 5.7 and 7.8, respectively. The increase in roughness continued with the grafting of $\mathrm{ZnO}$ NPs, but to a lesser extent, by a factor of 1.7 for $(S q)$, while the $(S p-S v)$ value remains relatively stable. The growth of the nanorods generated a variation in the two considered parameters by a factor of 2.9 and 2.4, respectively. The electro-polymerization of IIP produced a coating effect resulting in a significant decrease in the values of the two roughness parameters by a factor of 4.7 for $(S q)$ and 3.3 for $(S p-S v)$. These two parameters decreased by a factor of around 1.5 only, after the analyte extraction step. This slight decrease is probably due to the local rearrangements which occur once the $\mathrm{Hg}^{2+}$ ions are extracted from the polymer matrix.

The corresponding 2D images of ZnO NPs (Figure 8a) and ZnO NRs (Figure 8b), show the dimensions of the ZnO NPs and NRs. The diameter of the NPs is between 70 and $80 \mathrm{~nm}$, while that of the obtained NRs is in the range of 300-350 $\mathrm{nm}$ (the same diameter was obtained in our previous work [47]). Figure $8 \mathrm{c}, \mathrm{d}$ represents $2 \mathrm{D}$ and $3 \mathrm{D}$ images for the same analysis area on a surface of $\left(80 \times 80 \mu \mathrm{m}^{2}\right)$. The growth of NRs is generally homogeneous, and the height after growth of NRs reaches $325 \mathrm{~nm}$ (Figure $8 \mathrm{~d}$ ). 

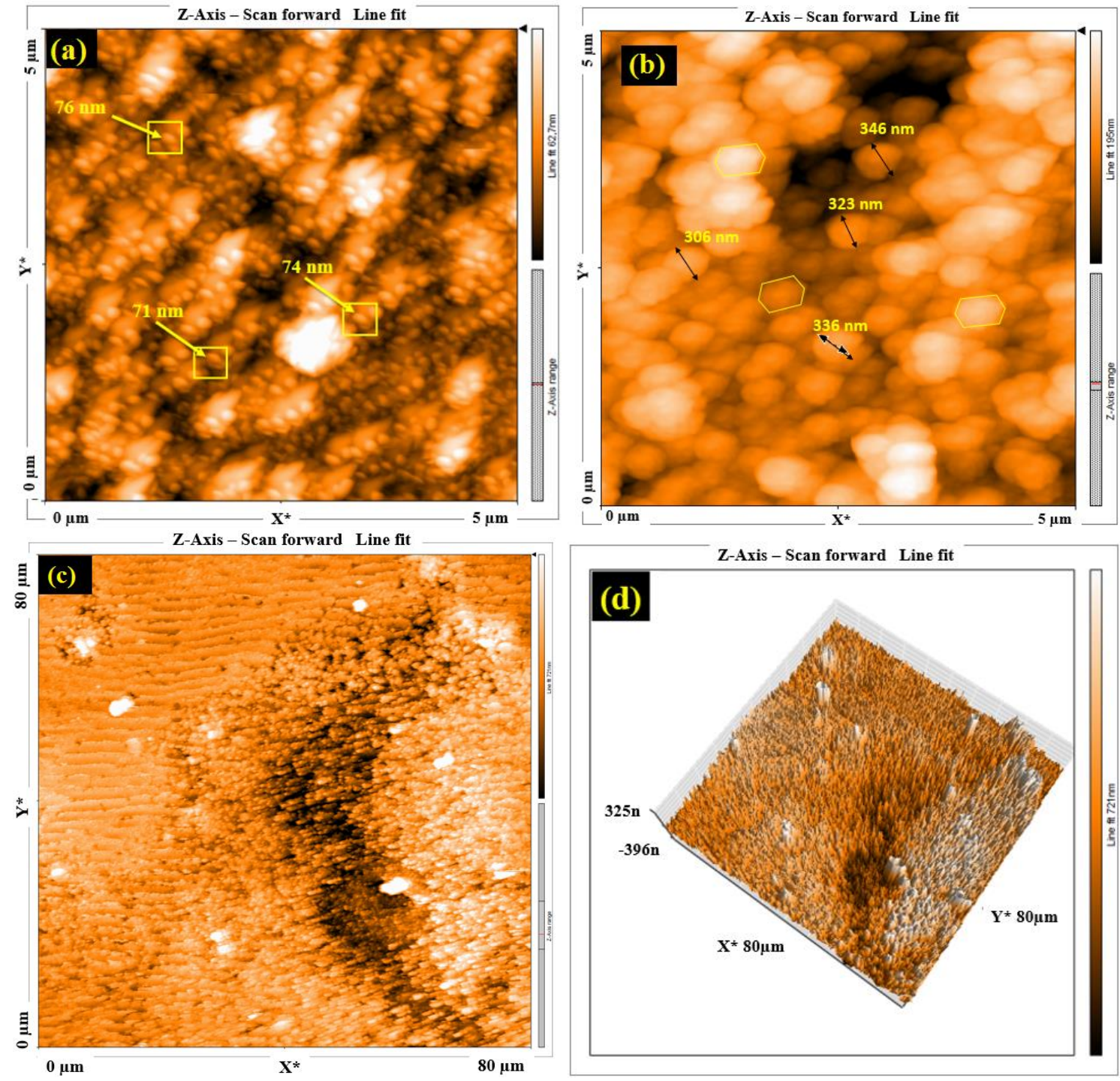

Figure 8. Two/three-dimensional images of Au-diazo-ZnO NPs and Au-diazo-ZnONRs. (a) Au-diazo-ZnO NPs with NPs diameter on $\left(5 \times 5 \mu \mathrm{m}^{2}\right)$ image, (b) NRs diameter on $\left(5 \times 5 \mu \mathrm{m}^{2}\right)$ image, (c) $\left(80 \times 80 \mu \mathrm{m}^{2}\right)$ 2D image of Au-diazo-ZnO NRs and (d) $\left(80 \times 80 \mu \mathrm{m}^{2}\right)$ 3D image of Au-diazo-ZnO NRs.

\subsection{Extraction Time in EDTA and Incubation Time in Mercury Solutions}

Ethylenedinitrilo tetraacetic acid (EDTA) has been used in this work to extract mercury ions from the $\mathrm{ZnO}$-IIP sensor. EDTA is an acid that is difficult to biodegrade. It is a stable chelator used in several applications, such as the medical field and the nuclear industry, but it is also used to adsorb heavy ions through functional groups, avoiding their precipitation [78-80]. Experiments (results not shown here) indicate that the optimum extraction was obtained by incubating the IIP in EDTA $0.1 \mathrm{M}$, for $20 \mathrm{~min}$, and by then rinsing the films for $10 \mathrm{~min}$ in ultra-pure water.

The film obtained after extraction was incubated in a mercury solution $\left(10^{-4} \mathrm{M}\right)$ for different periods of time. Results presented in Figure 9 indicate that the number of $\mathrm{Hg}^{2+}$ ions captured by the sensor increased only slightly between 20 and $40 \mathrm{~min}$, compared to the sharp increase between 5 and $20 \mathrm{~min}$ of incubation. For practical reasons, the incubation time was set to $20 \mathrm{~min}$. 


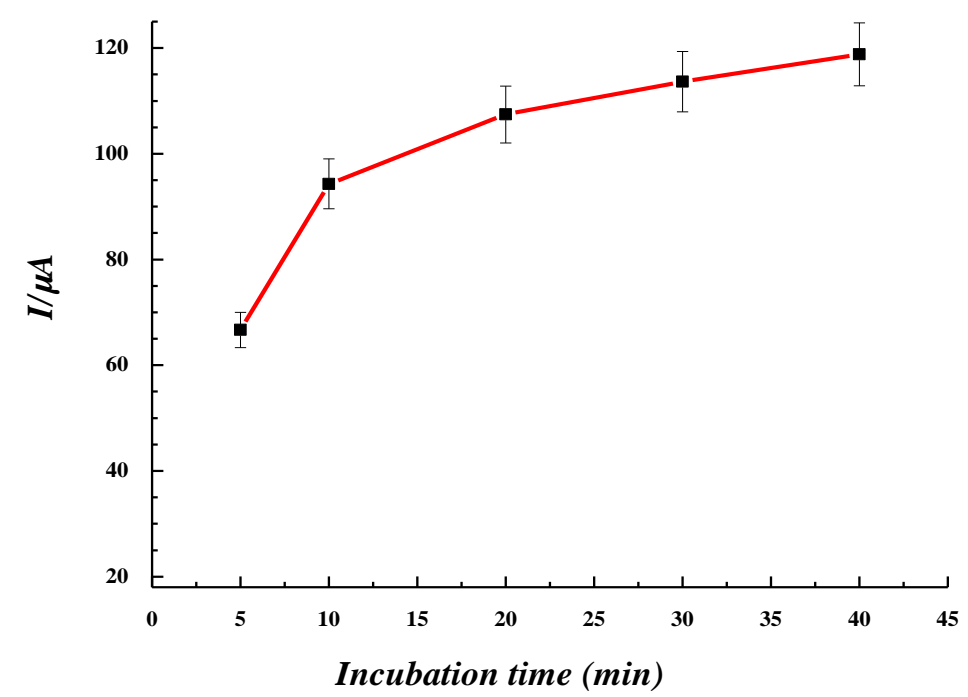

Figure 9. $\mathrm{Hg}$-IIP response after different incubation times in $10^{-4} \mathrm{M}$ mercury solution/ $\mathrm{H}_{2} \mathrm{O} / \mathrm{KCl} 0.1 \mathrm{M}$.

\subsection{Electrochemical Sensing of Mercury}

SWV was used to investigate the electrochemical response of the $\mathrm{ZnO} / \mathrm{Hg}^{2+}$-IIP sensor towards mercury in solution at different concentrations. Sensor response was recorded, via the characteristic peak current, for concentrations between $10^{-12}$ and $10^{-3} \mathrm{M}$ (Figure 10).

The sensor limit of detection (LOD) was determined from the lowest concentration that gave a visible signal $[81,82]$, instead of the method based on the signal to noise ratio of 3 , as usually done. Here, the obtained LOD of $1 \mathrm{pM}$ is much lower than the WHO maximum permissible limit in drinking water of $\left(1 \mu \mathrm{g} . \mathrm{L}^{-1}\right)$.

To confirm the performance of the sensor, this $\mathrm{Hg}^{2+}$ detection step was conducted on three different $\mathrm{ZnO} / \mathrm{Hg}^{2+}-\mathrm{IIP}$, and the average calibration curve is shown in Figure 11 (variations of output signal of electrochemical IIP-based sensor versus $\mathrm{Hg}^{2+}$ concentrations).

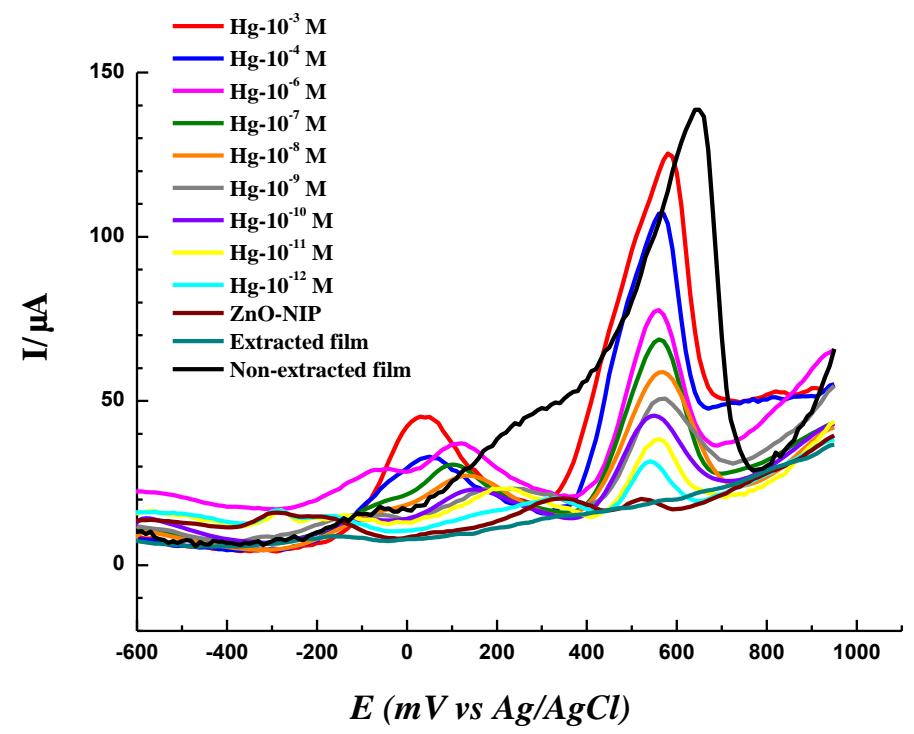

Figure 10. Follow-up of peak current variations (determined from SWV measurements in $\mathrm{H}_{2} \mathrm{O} / \mathrm{KCl}$ $0.1 \mathrm{M}$ solution) according to the potential. Conditions: E-pulse: $0.01 \mathrm{~V}$, E-step: $0.01 \mathrm{~V}$, frequency: $25 \mathrm{~Hz}$, equilibration time: $2 \mathrm{~s}$. 


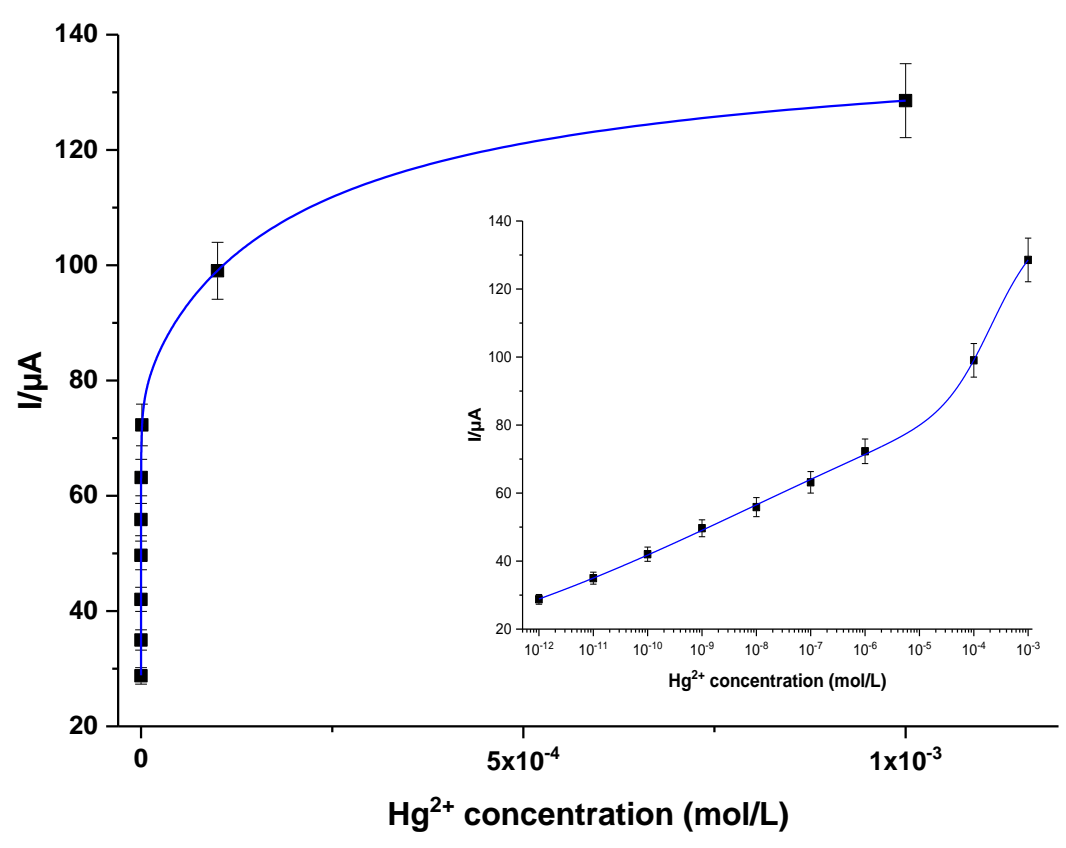

Figure 11. Peak current variation versus $\mathrm{Hg}^{2+}$ concentration; electrochemical experimental data were fitted by a combined model (one binding site + Hill model). The inset is added to highlight the goodness of the fit according to the proposed model.

The dissociation constant $K_{d}$ is an important parameter that determines the degree of affinity between the polymer and the template. Different analytical models were tested to fit the experimental data of the electrochemical measurements. The most appropriate one was a combination of the one site model and Hill model (Figure 11). The choice of this model makes it possible to take into consideration the mechanical restructuring of polymers at the nanometric scale [83].

$$
Y(C)=\frac{A_{1} \times C}{K_{d 1}+C}+\frac{A_{2} \times C^{\alpha}}{K_{d 2}^{\alpha}+C^{\alpha}}
$$

where $y(C)$ is the output sensor's signal response (current) for a given concentration $(C)$ of $\mathrm{Hg}^{2+}$. $K_{d 1}$, and $K_{d 2}$ are the first and second dissociation constants, $A_{1}$ and $A_{2}$ are empiric constants, and $\alpha$ is an empiric ponderation exponent. The values obtained for $K_{d 1}$ and $K_{d 2}$ were in the order of $(7.9 \pm 3.6) \mathrm{mM}$ and (38.1 \pm 9.2$) \mathrm{pM}$, respectively. The value of $K_{d 2}$ is consistent with that linked to the binding of $\mathrm{Hg}^{2+}$ to the Cys4 site in CP-CCCC peptide, which shows that the IIP can imitate biological entities in terms of affinity for heavy ions [71,83]. The $\alpha$ value of $0.06 \pm 0.002$, indicates positive cooperative interactions between $\mathrm{Hg}^{2+}$ ions and other binding sites [71].

The sensor sensitivity, computed from the slope at the origin of current/concentration curves (i.e., at lower concentrations), was in the order of $0.692 \pm 0.034 \mu \mathrm{A} \cdot \mathrm{pM}^{-1}$. This value shows that this LCys-PPy sensor prepared on $\mathrm{Au}-\mathrm{ZnO}$ to capture mercury is very sensitive compared to several sensors intended to detect heavy metals [84-86]. In addition to these interesting metrological features, we also tested the selectivity of the sensor by comparing the recognition of the targeted $\mathrm{Hg}^{2+}$ to lead, cadmium and copper ions. The rationale for this set of ions is the following: $\mathrm{Cd}^{2+}$ has an ionic radius close to that of $\mathrm{Hg}^{2+} ; \mathrm{Cu}^{2+}$ has a lower ionic radius than $\mathrm{Hg}^{2+}$, whereas $\mathrm{Pb}^{2+}$ is a larger ion than the targeted $\mathrm{Hg}^{2+}$.

We first incubated the extracted film in a solution containing an ion of the chosen ions with a concentration of $10^{-4} \mathrm{M}$ (Figure 12A). The second step was to mix several ions with $\mathrm{Hg}^{2+}$ with the same concentration of each ion (Figure 12B, black curve) and conduct another test in a solution containing $\mathrm{Pb}^{2+}$ and $\mathrm{Hg}^{2+}$ with a concentration of $\mathrm{Pb}^{2+}$ greater than 100 times that of $\mathrm{Hg}^{2+}$ (Figure 12B, red curve). 

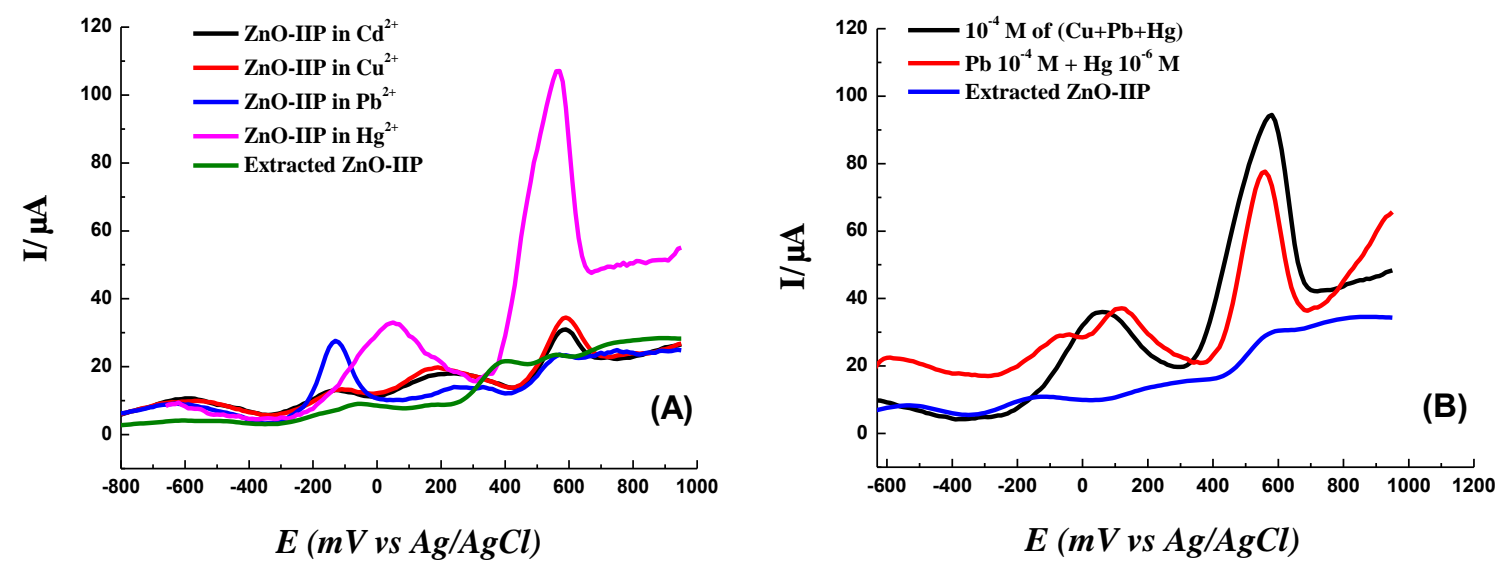

Figure 12. Evaluation of sensor's selectivity. (A): SWV curves in $\mathrm{H}_{2} \mathrm{O} / \mathrm{KCl} 0.1 \mathrm{M}$ solution of $\mathrm{ZnO} / \mathrm{Hg}$ (II)-IIP electrodes incubated in $10^{-4} \mathrm{M}$ solutions of either mercury, cadmium, lead or copper ions for $20 \mathrm{~min}$. (B): Competition tests. Conditions: E-pulse: $0.01 \mathrm{~V}$, E-step: $0.01 \mathrm{~V}$, frequency: $25 \mathrm{~Hz}$, equilibration time: $2 \mathrm{~s}$.

The incubation of the extracted film each time in $10^{-4} \mathrm{M}$ solution of a single chosen ion (Figure 12A) shows that $\mathrm{ZnO}-\mathrm{IIP}$ is specific for $\mathrm{Hg}^{2+}$.

The competition tests (Figure 12B) were carried out by incubating the extracted film in a solution containing equal concentrations $\left(10^{-4} \mathrm{M}\right)$ of $\mathrm{Cu}^{2+}, \mathrm{Hg}^{2+}$ and $\mathrm{Pb}^{2+}$ ions. The tests have shown that in the presence of $\mathrm{Cu}^{2+}$ and/or $\mathrm{Pb}^{2+}$, the extracted film detects $\mathrm{Hg}^{2+}$ highly selectively. One can note the existence of some competition, since in Figure 12A, the height of the $\mathrm{Hg}^{2+}$ peak is $106 \mu \mathrm{A}$ but slightly decreases to $94 \mu \mathrm{A}$ in the presence of both $\mathrm{Cu}^{2+}$ and $\mathrm{Pb}^{2+}$ at the same concentration of $10^{-4} \mathrm{M}$ (Figure 12B). If the $\mathrm{Hg}^{2+}$ concentration is decreased to $10^{-6} \mathrm{M}$, one can note a decrease in the height of the peak to $77 \mu \mathrm{A}$ in the presence of $10^{-4} \mathrm{M} \mathrm{Pb}^{2+}$ (Figure 12B). Quantitatively speaking, there is a clear selectivity of the sensor to $\mathrm{Hg}^{2+}$; indeed, competition of other ions to the artificial receptors occurs but remains marginal. This is very important to prove, because in most fundamental studies, selectivity tests are usually conducted in single metal ion solutions and not in mixtures [87].

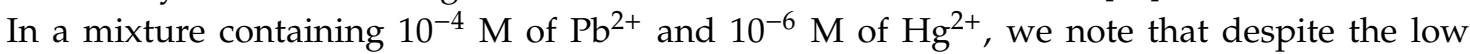
concentration of mercury with the presence of other ions, the sensor remains specific to $\mathrm{Hg}^{2+}$, hence the importance of shaping the receptor sites with this template. This also shows that there is no competitive chemisorption of $\mathrm{Pb}^{2+}$ which hampers the response of the sensor to the $\mathrm{Hg}^{2+}$ ions.

The performance of the IIP sensors designed so far is compared to that of a number of other sensors described in the literature (Table 2). Embedding $\mathrm{ZnO}$ nanorods in the IIP film provided a unique LOD, as low as $1 \mathrm{pM}$.

Table 2. Comparison of the analytical performance of $\mathrm{Au}-\mathrm{ZnO} / \mathrm{Hg}$-IIP to that of other handpicked relevant sensors reported in the literature.

\begin{tabular}{ccccc}
\hline Electrode & Analytical Method & Electrolyte & LOD & Ref \\
\hline $\begin{array}{c}\text { Glassy carbon electrode } \\
\text { GC/SH/AuNPs }\end{array}$ & $\begin{array}{c}\text { Square wave anodic } \\
\text { stripping voltammetry } \\
\text { (SWASV) }\end{array}$ & $\mathrm{HCl}$ solution & $10 \mathrm{nM}$ & {$[13]$} \\
\hline $\begin{array}{c}\text { Carbon-paste electrode } \\
(\mathrm{CPE})\end{array}$ & $\begin{array}{c}\text { Differential pulse } \\
\text { voltammetry (DPV) }\end{array}$ & $\mathrm{HCl}$ solution & $0.52 \mathrm{nM}$ & {$[31]$} \\
\hline
\end{tabular}


Table 2. Cont.

\begin{tabular}{|c|c|c|c|c|}
\hline Electrode & Analytical Method & Electrolyte & LOD & Ref \\
\hline Glassy carbon electrode & $\begin{array}{c}\text { Difference pulse } \\
\text { voltammetry (DPV) }\end{array}$ & PBS (pH 7.0) & $0.42 \mathrm{nM}$ & [88] \\
\hline $\begin{array}{l}\text { Carbon-paste electrode } \\
\text { (CPE) }\end{array}$ & $\begin{array}{c}\text { Electrochemical } \\
\text { Impedance Spectroscopy } \\
\text { (EIS) }\end{array}$ & Nitrate solution & $1.95 \mathrm{nM}$ & [89] \\
\hline $\begin{array}{c}\text { Commercial } \\
\text { screen-printed carbon } \\
\text { electrode (SPCE) }\end{array}$ & $\begin{array}{c}\text { Differential pulse } \\
\text { voltammetry (DPV) }\end{array}$ & $\begin{array}{l}\mathrm{KNO}_{3} / \mathrm{HNO}_{3} \\
\quad \text { solution } \\
\quad(\mathrm{pH} 2.7)\end{array}$ & $0.104 \mathrm{nM}$ & [90] \\
\hline Glassy carbon electrode & $\begin{array}{l}\text { Square wave anodic } \\
\text { stripping voltammetry } \\
\text { (SWASV) }\end{array}$ & $\begin{array}{l}\mathrm{K}_{3}\left[\mathrm{Fe}(\mathrm{CN})_{6}\right] \\
\text { solution }\end{array}$ & $0.1 \mathrm{nM}$ & [91] \\
\hline $\begin{array}{l}\text { Carbon paste electrode } \\
\text { (CPE) }\end{array}$ & $\begin{array}{l}\text { Square wave anodic } \\
\text { stripping voltammetry } \\
\text { (SWASV) }\end{array}$ & $\mathrm{HCl}$ solution & $18 \mathrm{pM}$ & [92] \\
\hline $\begin{array}{l}\text { Glassy carbon electrode } \\
\text { (GCE) }\end{array}$ & $\begin{array}{c}\text { Differential pulse } \\
\text { voltammetry (DPV) }\end{array}$ & $\begin{array}{c}\text { PBS } \\
(\mathrm{pH} 7.0)\end{array}$ & $0.2 \mu \mathrm{M}$ & [93] \\
\hline $\begin{array}{c}\text { Carbon } \\
\text { nanomaterials/AuNPs }\end{array}$ & $\begin{array}{c}\text { Anodic stripping } \\
\text { voltammetry (ASV) }\end{array}$ & $\mathrm{KCl}$ solution & $0.03 \mu \mathrm{M}$ & [94] \\
\hline $\begin{array}{l}\text { Mechanical Pencil Lead- } \\
\text { NiS/Reduced Graphene } \\
\text { Oxide }\end{array}$ & $\begin{array}{l}\text { Anodic stripping } \\
\text { voltammetry }\end{array}$ & PBS $1 \mathrm{mg} / \mathrm{mL}$ & $0.8 \mathrm{nM}$ & [95] \\
\hline $\begin{array}{c}\text { Platinum/(D) mordenite } \\
\text { decorated modified } \\
\text { glassy carbon electrode } \\
\text { (GCE) }\end{array}$ & Cyclic voltammetry (CV) & $\mathrm{KCl}$ solution & $3.4 \mathrm{nM}$ & [96] \\
\hline $\begin{array}{l}\text { Gold/polyethylene } \\
\text { terephthalate (PET) }\end{array}$ & $\begin{array}{l}\text { Differential pulse } \\
\text { voltammetry }\end{array}$ & $\mathrm{HNO}_{3} / \mathrm{KCl}$ & $2.49 \mathrm{nM}$ & [97] \\
\hline $\begin{array}{c}\text { Zincophosphite NPs } \\
\text { (NTOU4nano)/polyaniline } \\
\text { (PANI) }\end{array}$ & $\begin{array}{l}\text { Differential pulse } \\
\text { voltammetry }\end{array}$ & $\begin{array}{c}\text { PBS } \\
(\mathrm{pH} 7.0)\end{array}$ & $\begin{array}{c}3.49 .10^{-11} \\
\mathrm{M}\end{array}$ & [98] \\
\hline $\begin{array}{l}\text { Zinc oxide nanorods } \\
\text { grafted on a Gold } \\
\text { electrode }\end{array}$ & $\begin{array}{c}\text { Square Wave } \\
\text { Voltammetry (SWV) }\end{array}$ & $\mathrm{KCl}$ solution & $1 \mathrm{pM}$ & This work \\
\hline
\end{tabular}

\section{Conclusions}

A new electrochemical sensor based on a biomimetic ion-imprinted polymer for the detection of mercury (II) traces was prepared on a gold electrode with a strategy based on the combination of the surface modification with a diazonium salt and the growth of $\mathrm{ZnO}$ nanorods followed by electropolymerization of the pyrrole in the presence of the template $\left(\mathrm{Hg}^{2+}\right)$ and $\mathrm{L}$-cysteine as crosslinker. These two steps (diazonium salt and $\mathrm{ZnO}$ nanorods) permitted us to increase the performance of the final sensor (Au-diazo-ZnO/IIP) in terms of selectivity and limit of detection (LOD), which is in the picomolar range. This is proven by investigating the performance of an IIP prepared directly on a bare gold electrode, without any surface modification and in the absence of any $\mathrm{ZnO}$ nanorods.

The fit of the electrochemical results obtained by the one site/Hill model allowed us to determine the dissociation constants $\left[K_{d 1}=(7.89 \pm 3.63) \mathrm{mM}\right.$ and $\left.K_{d 2}=(38.10 \pm 9.22) \mathrm{pM}\right]$ as well as the sensitivity, which was equal to $0.692 \pm 0.034 \mu \mathrm{A} \cdot \mathrm{pM}^{-1}$.

The competitivity and selectivity tests were undertaken using several ions such as $\mathrm{Cu}^{2+}, \mathrm{Pb}^{2+}$ and $\mathrm{Cd}^{2+}$, taking into account the ionic radius and their concentration in an aqueous medium. IIP showed excellent ability to distinguish between mercury and different competitive ions even at 
low concentrations. Au-diazo-ZnO/IIP can therefore be used for environmental applications to detect mercury in the laboratory or for field analysis using a portable potensiostat.

Author Contributions: Conceptualization of the research work by Z.A.-T., N.F., C.Z.; Methodology by Z.A.-T., N.F., C.Z., M.M.C.; Validation by Z.A.-T., N.F., C.Z., R.T., M.M.C.; Formal Analysis by Z.A.-T., H.E.E.Y.S., N.F., C.Z., N.M., N.Y., M.M.C.; Writing of Original Draft was done by Z.A.-T., N.F., C.Z., M.M.C.; Writing: Review and Editing by Z.A.-T., H.E.E.Y.S., N.F., C.Z., N.M., N.Y., R.T., M.M.C.; Supervision: N.F., C.Z., R.T., M.M.C.; Funding Acquisition: N.F., C.Z., N.M., N.Y., R.T. All authors have read and agreed to the published version of the manuscript.

Funding: This research was funded by La Région Pays de Loire, grant No LMAC/MEMSAW (recipient: N.Y.) and by the Algerian Ministry of Higher Education and Scientific Research, grant number PNE 474 (recipient: H.E.E.Y.S.).

Acknowledgments: The authors are indebted to SATIE and ICMPE for internal financing to support the project.

Conflicts of Interest: The authors declare no conflict of interest.

\section{References}

1. Pacyna, E.G.; Pacyna, J.M. Global Emission of Mercury from Anthropogenic Sources in 1995. Water Air Soil Pollut. 2002, 137, 149-165. [CrossRef]

2. Tchounwou, P.B.; Ayensu, W.K.; Ninashvili, N.; Sutton, D. Environmental exposure to mercury and its toxicopathologic implications for public health. Environ. Toxicol. Int. J. 2003, 18, 149-175. [CrossRef]

3. Flanders, J.R.; Long, G.; Reese, B.; Grosso, N.R.; Clements, W.; Stahl, R.G. Assessment of potential mercury toxicity to native invertebrates in a high-gradient stream. Integr. Environ. Assess. Manag. 2019, 15, 374-384. [CrossRef] [PubMed]

4. Sall, M.L.; Fall, B.; Diédhiou, I.; Dièye, E.H.; Lo, M.; Diaw, A.K.D.; Gningue-Sall, D.; Raouafi, N.; Fall, M. Toxicity and Electrochemical Detection of Lead, Cadmium and Nitrite Ions by Organic Conducting Polymers: A Review. Chem. Afr. 2020. [CrossRef]

5. Hande, P.E.; Samui, A.B.; Kulkarni, P.S. Selective nanomolar detection of mercury using coumarin based fluorescent $\mathrm{Hg}$ (II)-Ion imprinted polymer. Sens. Actuators B Chem. 2017, 246, 597-605. [CrossRef]

6. Li, X.; Li, Z.; Wu, T.; Chen, J.; Fu, C.; Zhang, L.; Feng, X.; Fu, X.; Tang, L.; Wang, Z.; et al. Atmospheric mercury emissions from two pre-calciner cement plants in Southwest China. Atmos. Environ. 2019, 199, 177-188. [CrossRef]

7. Green, C.S.; Lewis, P.J.; Wozniak, J.R.; Drevnick, P.E.; Thies, M.L. A comparison of factors affecting the small-scale distribution of mercury from artisanal small-scale gold mining in a Zimbabwean stream system. Sci. Total Environ. 2019, 647, 400-410. [CrossRef]

8. Balasundaram, K.; Sharma, M. Technology for mercury removal from flue gas of coal based thermal power plants: A comprehensive review. Crit. Rev. Environ. Sci. Technol. 2019, 48, 1-37. [CrossRef]

9. D'ltri, P.A.; D'ltri, F.M. Mercury contamination: A human tragedy. Environ. Manag. 1978, 2, 3-16. [CrossRef]

10. Vijayaraghavan, K.; Yun, Y.-S. Bacterial biosorbents and biosorption. Biotechnol. Adv. 2008, 26, $266-291$. [CrossRef]

11. Cariccio, V.L.; Samà, A.; Bramanti, P.; Mazzon, E. Mercury Involvement in Neuronal Damage and in Neurodegenerative Diseases. Biol. Trace Elem. Res. 2019, 187, 341-356. [CrossRef] [PubMed]

12. Chen, G.; Guo, Z.; Zeng, G.; Tang, L. Fluorescent and colorimetric sensors for environmental mercury detection. Analyst 2015, 140, 5400-5443. [CrossRef] [PubMed]

13. Fezai, F.; Gros, P.; Meireles, M.; Evrard, D. New Electrochemical Sensor for Hg(II) Trace Detection in Natural Waters: Electrode Functionalization with Gold Nanoparticles and Diazonium Salts. Meet. Abstr. 2019, MA2019-01, 2010.

14. Piletsky, S.A.; Turner, A.P.F. Electrochemical Sensors Based on Molecularly Imprinted Polymers. Electroanalysis 2002, 14, 317-323. [CrossRef]

15. Salmi, Z.; Benzarti, K.; Chehimi, M.M. Diazonium Cation-Exchanged Clay: An Efficient, Unfrequented Route for Making Clay/Polymer Nanocomposites. Langmuir 2013, 29, 13323-13328. [CrossRef] [PubMed]

16. Msaadi, R.; Ammar, S.; Chehimi, M.M.; Yagci, Y. Diazonium-based ion-imprinted polymer/clay nanocomposite for the selective extraction of lead (II) ions in aqueous media. Eur. Polym. J. 2017, 89, 367-380. [CrossRef] 
17. Lo, M.; Ktari, N.; Gningue-Sall, D.; Madani, A.; Aaron, S.E.; Aaron, J.-J.; Mekhalif, Z.; Delhalle, J.; Chehimi, M.M. Polypyrrole: A reactive and functional conductive polymer for the selective electrochemical detection of heavy metals in water. Emergent Mater. 2020, 1-25. [CrossRef]

18. Ktari, N.; Fourati, N.; Zerrouki, C.; Ruan, M.; Seydou, M.; Barbaut, F.; Nal, F.; Yaakoubi, N.; Chehimi, M.M.; Kalfat, R. Design of a polypyrrole MIP-SAW sensor for selective detection of flumequine in aqueous media. Correlation between experimental results and DFT calculations. RSC Adv. 2015, 5, 88666-88674. [CrossRef]

19. Bahrami, A.; Besharati-Seidani, A.; Abbaspour, A.; Shamsipur, M. A highly selective voltammetric sensor for nanomolar detection of mercury ions using a carbon ionic liquid paste electrode impregnated with novel ion imprinted polymeric nanobeads. Mater. Sci. Eng. C 2015, 48, 205-212. [CrossRef] [PubMed]

20. Li, Z.-C.; Fan, H.-T.; Zhang, Y.; Chen, M.-X.; Yu, Z.-Y.; Cao, X.-Q.; Sun, T. Cd(II)-imprinted polymer sorbents prepared by combination of surface imprinting technique with hydrothermal assisted sol-gel process for selective removal of cadmium(II) from aqueous solution. Chem. Eng. J. 2011, 171, 703-710. [CrossRef]

21. Karrat, A.; Lamaoui, A.; Amine, A.; Palacios-Santander, J.M.; Cubillana-Aguilera, L. Applications of Chitosan in Molecularly and Ion Imprinted Polymers. Chem. Afr. 2020. [CrossRef]

22. Fayazi, M.; Ghanei-Motlagh, M.; Taher, M.A.; Ghanei-Motlagh, R.; Salavati, M.R. Synthesis and application of a novel nanostructured ion-imprinted polymer for the preconcentration and determination of thallium(I) ions in water samples. J. Hazard. Mater. 2016, 309, 27-36. [CrossRef] [PubMed]

23. Rajabi, H.R.; Razmpour, S. Synthesis, characterization and application of ion imprinted polymeric nanobeads for highly selective preconcentration and spectrophotometric determination of $\mathrm{Ni2}+$ ion in water samples. Spectrochim. Acta Part A Mol. Biomol. Spectrosc. 2016, 153, 45-52. [CrossRef] [PubMed]

24. Ashkenani, H.; Taher, M.A. Use of ionic liquid in simultaneous microextraction procedure for determination of gold and silver by ETAAS. Microchem. J. 2012, 103, 185-190. [CrossRef]

25. Fu, J.; Chen, L.; Li, J.; Zhang, Z. Current status and challenges of ion imprinting. J. Mater. Chem. A 2015, 3, 13598-13627. [CrossRef]

26. García-Otero, N.; Teijeiro-Valiño, C.; Otero-Romaní, J.; Peña-Vázquez, E.; Moreda-Piñeiro, A.; Moreda-Piñeiro, A. On-line ionic imprinted polymer selective solid-phase extraction of nickel and lead from seawater and their determination by inductively coupled plasma-optical emission spectrometry. Anal. Bioanal. Chem. 2009, 395, 1107-1115. [CrossRef] [PubMed]

27. Luo, X.; Liu, L.; Deng, F.; Luo, S. Novel ion-imprinted polymer using crown ether as a functional monomer for selective removal of $\mathrm{Pb}(\mathrm{II})$ ions in real environmental water samples. J. Mater. Chem. A 2013, 1, 8280-8286. [CrossRef]

28. Gawin, G.; Konefał, J.; Trzewik, B.; Walas, B.; Tobiasz, A.; Mrowiec, H.; Witek, E. Preparation of a new $\mathrm{Cd}(\mathrm{II})$-imprinted polymer and its application to determination of cadmium(II) via flow-injection-flame atomic absorption spectrometry. Talanta 2010, 80, 1305-1310. [CrossRef]

29. Abu-Dalo, M.A.; Al-Rawashdeh, N.A.F.; Al-Mheidat, I.R.; Nassory, N.S. Preparation and evaluation of new uranyl imprinted polymer electrode sensor for uranyl ion based on uranyl-carboxybezotriazole complex in pvc matrix membrane. Sens. Actuators B Chem. 2016, 227, 336-345. [CrossRef]

30. Güney, S.; Güney, O. A novel electrochemical sensor for selective determination of uranyl ion based on imprinted polymer sol-gel modified carbon paste electrode. Sens. Actuators B Chem. 2016, 231, 45-53. [CrossRef]

31. Alizadeh, T.; Ganjali, M.R.; Zare, M. Application of an $\mathrm{Hg} 2+$ selective imprinted polymer as a new modifying agent for the preparation of a novel highly selective and sensitive electrochemical sensor for the determination of ultratrace mercury ions. Anal. Chim. Acta 2011, 689, 52-59. [CrossRef] [PubMed]

32. Rajabi, H.R.; Roushani, M.; Shamsipur, M. Development of a highly selective voltammetric sensor for nanomolar detection of mercury ions using glassy carbon electrode modified with a novel ion imprinted polymeric nanobeads and multi-wall carbon nanotubes. J. Electroanal. Chem. 2013, 693, 16-22. [CrossRef]

33. Fu, X.-C.; Wu, J.; Nie, L.; Xie, C.-G.; Liu, J.-H.; Huang, X.-J. Electropolymerized surface ion imprinting films on a gold nanoparticles/single-wall carbon nanotube nanohybrids modified glassy carbon electrode for electrochemical detection of trace mercury(II) in water. Anal. Chim. Acta 2012, 720, 29-37. [CrossRef] [PubMed] 
34. Fu, X.-C.; Chen, X.; Guo, Z.; Xie, C.-G.; Kong, L.-T.; Liu, J.-H.; Huang, X.-J. Stripping voltammetric detection of mercury(II) based on a surface ion imprinting strategy in electropolymerized microporous poly(2-mercaptobenzothiazole) films modified glassy carbon electrode. Anal. Chim. Acta 2011, 685, 21-28. [CrossRef]

35. Li, M.; Gou, H.; Al-Ogaidi, I.; Wu, N. Nanostructured Sensors for Detection of Heavy Metals: A Review. ACS Sustain. Chem. Eng. 2013, 1, 713-723. [CrossRef]

36. Ait-Touchente, Z.; Falah, S.; Scavetta, E.; Chehimi, M.M.; Touzani, R.; Tonelli, D.; Taleb, A. Different Electrochemical Sensor Designs Based on Diazonium Salts and Gold Nanoparticles for Pico Molar Detection of Metals. Molecules 2020, 25, 3903. [CrossRef]

37. Galstyan, V.; Comini, E.; Baratto, C.; Faglia, G.; Sberveglieri, G. Nanostructured ZnO chemical gas sensors. Ceram. Int. 2015, 41, 14239-14244. [CrossRef]

38. Litton, C.W.; Collins, T.C.; Reynolds, D.C. Zinc Oxide Materials for Electronic and Optoelectronic Device Applications; John Wiley \& Sons: Hoboken, NJ, USA, 2011; ISBN 978-1-119-99121-2.

39. Özgür, Ü.; Alivov, Y.I.; Liu, C.; Teke, A.; Reshchikov, M.A.; Doğan, S.; Avrutin, V.; Cho, S.-J.; Morkoç, H. A comprehensive review of $\mathrm{ZnO}$ materials and devices. J. Appl. Phys. 2005, 98, 041301. [CrossRef]

40. Luz, G.; Hidalgo, P.; Hui, W.; Nogeuira, P.; Brasil, L. Assembly and Characterization of ZnO nanoparticles for Gratzels Solar Cell. Adv. Mater. Lett. 2018, 9, 284-289. [CrossRef]

41. Meng, P.; Zhao, X.; Yang, X.; Wu, J.; Xie, Q.; He, J.; Hu, J.; He, J. Breakdown phenomenon of ZnO varistors caused by non-uniform distribution of internal pores. J. Eur. Ceram. Soc. 2019, 39, 4824-4830. [CrossRef]

42. Jiang, M.; Mao, W.; Zhou, X.; Kan, C.; Shi, D. Wavelength-tunable waveguide emissions from electrically driven single $\mathrm{ZnO} / \mathrm{ZnO}$ : Ga superlattice microwires. ACS Appl. Mater. Interfaces 2019, 11, 11800-11811. [CrossRef]

43. Ding, M.; Guo, Z.; Zhou, L.; Fang, X.; Zhang, L.; Zeng, L.; Xie, L.; Zhao, H. One-Dimensional Zinc Oxide Nanomaterials for Application in High-Performance Advanced Optoelectronic Devices. Crystals 2018, 8, 223. [CrossRef]

44. Wei, A.; Pan, L.; Huang, W. Recent progress in the ZnO nanostructure-based sensors. Mater. Sci. Eng. B 2011, 176, 1409-1421. [CrossRef]

45. Liu, X.; Zhang, J.; Wang, L.; Yang, T.; Guo, X.; Wu, S.; Wang, S. 3D hierarchically porous ZnO structures and their functionalization by Au nanoparticles for gas sensors. J. Mater. Chem. 2010, 21, 349-356. [CrossRef]

46. Hjiri, M.; El Mir, L.; Leonardi, S.G.; Pistone, A.; Mavilia, L.; Neri, G. Al-doped ZnO for highly sensitive CO gas sensors. Sens. Actuators B Chem. 2014, 196, 413-420. [CrossRef]

47. Mekki, A.; Ait-Touchente, Z.; Samanta, S.; Singh, A.; Mahmoud, R.; Chehimi, M.M.; Aswal, D.K. Polyaniline-Wrapped ZnO Nanorod Composite Films on Diazonium-Modified Flexible Plastic Substrates. Macromol. Chem. Phys. 2016, 217, 1136-1148. [CrossRef]

48. Deng, X.; Zhang, L.; Guo, J.; Chen, Q.; Ma, J. ZnO enhanced NiO-based gas sensors towards ethanol. Mater. Res. Bull. 2017, 90, 170-174. [CrossRef]

49. Navale, Y.H.; Navale, S.T.; Ramgir, N.S.; Stadler, F.J.; Gupta, S.K.; Aswal, D.K.; Patil, V.B. Zinc oxide hierarchical nanostructures as potential $\mathrm{NO}_{2}$ sensors. Sens. Actuators B Chem. 2017, 251, 551-563. [CrossRef]

50. Shetti, N.P.; Bukkitgar, S.D.; Reddy, K.R.; Reddy, C.V.; Aminabhavi, T.M. ZnO-based nanostructured electrodes for electrochemical sensors and biosensors in biomedical applications. Biosens. Bioelectron. 2019, 141, 111417. [CrossRef]

51. Wu, J.-J.; Liu, S.-C. Low-temperature growth of well-aligned $\mathrm{ZnO}$ nanorods by chemical vapor deposition. Adv. Mater. 2002, 14, 215-218. [CrossRef]

52. Ashour, A.; Kaid, M.A.; El-Sayed, N.Z.; Ibrahim, A.A. Physical properties of ZnO thin films deposited by spray pyrolysis technique. Appl. Surf. Sci. 2006, 252, 7844-7848. [CrossRef]

53. Banerjee, A.N.; Ghosh, C.K.; Chattopadhyay, K.K.; Minoura, H.; Sarkar, A.K.; Akiba, A.; Kamiya, A.; Endo, T. Low-temperature deposition of $\mathrm{ZnO}$ thin films on PET and glass substrates by DC-sputtering technique. Thin Solid Film. 2006, 496, 112-116. [CrossRef]

54. Sun, X.W.; Kwok, H.S. Optical properties of epitaxially grown zinc oxide films on sapphire by pulsed laser deposition. J. Appl. Phys. 1999, 86, 408-411. [CrossRef]

55. Jeong, S.-H.; Kim, B.-S.; Lee, B.-T. Photoluminescence dependence of ZnO films grown on Si (100) by radio-frequency magnetron sputtering on the growth ambient. Appl. Phys. Lett. 2003, 82, 2625-2627. [CrossRef] 
56. Jin, B.J.; Im, S.; Lee, S.Y. Violet and UV luminescence emitted from $\mathrm{ZnO}$ thin films grown on sapphire by pulsed laser deposition. Thin Solid Film. 2000, 366, 107-110. [CrossRef]

57. Yi, J.B.; Pan, H.; Lin, J.Y.; Ding, J.; Feng, Y.P.; Thongmee, S.; Liu, T.; Gong, H.; Wang, L. Ferromagnetism in ZnO Nanowires Derived from Electro-deposition on AAO Template and Subsequent Oxidation. Adv. Mater. 2008, 20, 1170-1174. [CrossRef]

58. Thongsuriwong, K.; Amornpitoksuk, P.; Suwanboon, S. Structure, morphology, photocatalytic and antibacterial activities of $\mathrm{ZnO}$ thin films prepared by sol-gel dip-coating method. Adv. Powder Technol. 2013, 24, 275-280. [CrossRef]

59. Greene, L.E.; Law, M.; Goldberger, J.; Kim, F.; Johnson, J.C.; Zhang, Y.; Saykally, R.J.; Yang, P. Low-temperature wafer-scale production of ZnO nanowire arrays. Angew. Chem. 2003, 115, 3139-3142. [CrossRef]

60. Pacholski, C.; Kornowski, A.; Weller, H. Self-Assembly of ZnO: From Nanodots to Nanorods. Angew. Chem. Int. Ed. 2002, 41, 1188-1191. [CrossRef]

61. Chander, R.; Raychaudhuri, A.K. Growth of aligned arrays of $\mathrm{ZnO}$ nanorods by low temperature solution method on Si surface. J. Mater. Sci. 2006, 41, 3623-3630. [CrossRef]

62. Kołodziejczak-Radzimska, A.; Jesionowski, T. Zinc Oxide-From Synthesis to Application: A Review. Materials 2014, 7, 2833-2881. [CrossRef]

63. Mazouz, Z.; Touchente, Z.A.; Laradi, H.; Fourati, N.; Yaakoubi, N.; Touzani, R.; Chehimi, M.M.; Kalfat, R.; Othmane, A.; Zerrouki, C. Design of Novel Electrochemical Sensors for the Selective Detection of Glyphosate. In Proceedings of the Eurosensors 2017, Paris, France, 3-6 September 2017; Volume 1, p. 483. [CrossRef]

64. Ait-Touchente, Z.; Sakhraoui, H.E.E.Y.; Fourati, N.; Zerrouki, C.; Maouche, N.; Touzani, R.; Yaakoubi, N.; Chehimi, M.M. Zinc Oxide Nanorods Wrapped with Ion-Imprinted Polypyrrole Polymer for Picomolar Selective and Electrochemical Detection of Mercury II Ions. Proceedings 2018, 2, 1004. [CrossRef]

65. Lo, M.; Pires, R.; Diaw, K.; Gningue-Sall, D.; Oturan, M.A.; Aaron, J.-J.; Chehimi, M.M. Diazonium salts: Versatile molecular glues for sticking conductive polymers to flexible electrodes. Surfaces 2018, 1, 5. [CrossRef]

66. Adenier, A.; Bernard, M.-C.; Chehimi, M.M.; Cabet-Deliry, E.; Desbat, B.; Fagebaume, O.; Pinson, J.; Podvorica, F. Covalent Modification of Iron Surfaces by Electrochemical Reduction of Aryldiazonium Salts. J. Am. Chem. Soc. 2001, 123, 4541-4549. [CrossRef] [PubMed]

67. Hasanpoor, M.; Aliofkhazraei, M.; Delavari, H. Microwave-assisted synthesis of zinc oxide nanoparticles. Procedia Mater. Sci. 2015, 11, 320-325. [CrossRef]

68. Vasjari, M.; Shirshov, Y.M.; Samoylov, A.V.; Mirsky, V.M. SPR investigation of mercury reduction and oxidation on thin gold electrodes. J. Electroanal. Chem. 2007, 605, 73-76. [CrossRef]

69. Manceau, A.; Nagy, L.K. Relationships between $\mathrm{Hg}(\mathrm{ii})-\mathrm{S}$ bond distance and $\mathrm{Hg}$ ( ii ) coordination in thiolates. Dalton Trans. 2008, 11, 1421-1425. [CrossRef]

70. Berthon, G. Critical evaluation of the stability constants of metal complexes of amino acids with polar side chains (Technical Report). Pure Appl. Chem. 1995, 67, 1117-1240. [CrossRef]

71. Sakhraoui, H.E.E.Y.; Mazouz, Z.; Attia, G.; Fourati, N.; Zerrouki, C.; Maouche, N.; Othmane, A.; Yaakoubi, N.; Kalfat, R.; Madani, A.; et al. Design of L-Cysteine and Acrylic Acid Imprinted Polypyrrole Sensors for Picomolar Detection of Lead Ions in Simple and Real Media. IEEE Sens. J. 2019, 20, 4147-4155. [CrossRef]

72. Ding, N.; Zhao, H.; Peng, W.; He, Y.; Zhou, Y.; Yuan, L.; Zhang, Y. A simple colorimetric sensor based on anti-aggregation of gold nanoparticles for Hg2+ detection. Colloids Surf. A Physicochem. Eng. Asp. 2012, 395, 161-167. [CrossRef]

73. Mah, V.; Jalilehvand, F. Mercury (II) complex formation with glutathione in alkaline aqueous solution. JBIC J. Biol. Inorg. Chem. 2008, 13, 541-553. [CrossRef] [PubMed]

74. Ballav, N.; Das, R.; Giri, S.; Muliwa, A.M.; Pillay, K.; Maity, A. L-cysteine doped polypyrrole (PPy@ L-Cyst): A super adsorbent for the rapid removal of $\mathrm{Hg}+2$ and efficient catalytic activity of the spent adsorbent for reuse. Chem. Eng. J. 2018, 345, 621-630. [CrossRef]

75. Claude, B. Intérêt des Polymères à Empreintes Moléculaires pour la Préparation d'Echantillons par Extraction Solide-Liquide. Application aux Triterpènes dans les Plantes et aux Dopants Dans Les Urines; Université D’Orléans: Orléans, France, 2007; Available online: https:/tel.archives-ouvertes.fr/tel-00148669/ (accessed on 5 September 2020).

76. Watson, C.M.; Dwyer, D.J.; Andle, J.C.; Bruce, A.E.; Bruce, M.R.M. Stripping Analyses of Mercury Using Gold Electrodes: Irreversible Adsorption of Mercury. Anal. Chem. 1999, 71, 3181-3186. [CrossRef] [PubMed] 
77. Ordeig, O.; Banks, C.E.; del Campo, J.; Muñoz, F.X.; Compton, R.G. Trace Detection of Mercury(II) Using Gold Ultra-Microelectrode Arrays. Electroanalysis 2006, 18, 573-578. [CrossRef]

78. Teng, Z.; Lv, H.; Wang, L.; Liu, L.; Wang, C.; Wang, G. Voltammetric Sensor Modified by EDTA-immobilized Graphene-like Carbon Nitride Nanosheets: Preparation, Characterization and Selective Determination of Ultra-Trace Pb (II) in Water Samples. Electrochim. Acta 2016, 212, 722-733. [CrossRef]

79. Repo, E.; Malinen, L.; Koivula, R.; Harjula, R.; Sillanpää, M. Capture of Co(II) from its aqueous EDTA-chelate by DTPA-modified silica gel and chitosan. J. Hazard. Mater. 2011, 187, 122-132. [CrossRef] [PubMed]

80. Hinck, M.L.; Ferguson, J.; Puhaakka, J. Resistance of EDTA and DTPA to aerobic biodegradation. Water Sci. Technol. 1997, 35, 25-31. [CrossRef]

81. Toh, H.S.; Batchelor-McAuley, C.; Tschulik, K.; Damm, C.; Compton, R.G. A proof-of-concept-Using pre-created nucleation centres to improve the limit of detection in anodic stripping voltammetry. Sens. Actuators B Chem. 2014, 193, 315-319. [CrossRef]

82. Attia, G.; Rahali, S.; Teka, S.; Fourati, N.; Zerrouki, C.; Seydou, M.; Chehimi, S.; Hayouni, S.; Mbakidi, J.-P.; Bouquillon, S.; et al. Anthracene based surface acoustic wave sensors for picomolar detection of lead ions. Correlation between experimental results and DFT calculations. Sens. Actuators B Chem. 2018, 276, 349-355. [CrossRef]

83. Mazouz, Z.; Rahali, S.; Fourati, N.; Zerrouki, C.; Aloui, N.; Seydou, M.; Yaakoubi, N.; Chehimi, M.M.; Othmane, A.; Kalfat, R. Highly Selective Polypyrrole MIP-Based Gravimetric and Electrochemical Sensors for Picomolar Detection of Glyphosate. Sensors 2017, 17, 2586. [CrossRef]

84. Roushani, M.; Saedi, Z.; Hamdi, F.; Dizajdizi, B.Z. Preparation an electrochemical sensor for detection of manganese (II) ions using glassy carbon electrode modified with multi walled carbon nanotube-chitosan-ionic liquid nanocomposite decorated with ion imprinted polymer. J. Electroanal. Chem. 2017, 804, 1-6. [CrossRef]

85. Alizadeh, T.; Rafiei, F.; Hamidi, N.; Ganjali, M.R. A new electrochemical sensing platform for Cr (III) determination based on nano-structured $\mathrm{Cr}$ (III)-imprinted polymer-modified carbon composite electrode. Electrochim. Acta 2017, 247, 812-819. [CrossRef]

86. Alizadeh, T.; Hamidi, N.; Ganjali, M.R.; Rafiei, F. An extraordinarily sensitive voltammetric sensor with picomolar detection limit for $\mathrm{Pb} 2+$ determination based on carbon paste electrode impregnated with nano-sized imprinted polymer and multi-walled carbon nanotubes. J. Environ. Chem. Eng. 2017, 5, 4327-4336. [CrossRef]

87. Lo, M.; Seydou, M.; Bensghaïer, A.; Pires, R.; Gningue-Sall, D.; Aaron, J.-J.; Mekhalif, Z.; Delhalle, J.; Chehimi, M.M. Polypyrrole-Wrapped Carbon Nanotube Composite Films Coated on Diazonium-Modified Flexible ITO Sheets for the Electroanalysis of Heavy Metal Ions. Sensors 2020, 20, 580. [CrossRef] [PubMed]

88. Karthika, A.; Ramasamy Raja, V.; Karuppasamy, P.; Suganthi, A.; Rajarajan, M. Electrochemical behaviour and voltammetric determination of mercury (II) ion in cupric oxide/poly vinyl alcohol nanocomposite modified glassy carbon electrode. Microchem. J. 2019, 145, 737-744. [CrossRef]

89. Shirzadmehr, A.; Afkhami, A.; Madrakian, T. A new nano-composite potentiometric sensor containing an $\mathrm{Hg} 2+-$ ion imprinted polymer for the trace determination of mercury ions in different matrices. J. Mol. Liq. 2015, 204, 227-235. [CrossRef]

90. Armas, M.A.; María-Hormigos, R.; Cantalapiedra, A.; Gismera, M.J.; Sevilla, M.T.; Procopio, J.R. Multiparametric optimization of a new high-sensitive and disposable mercury (II) electrochemical sensor. Anal. Chim. Acta 2016, 904, 76-82. [CrossRef]

91. Shah, A.; Sultan, S.; Zahid, A.; Aftab, S.; Nisar, J.; Nayab, S.; Qureshi, R.; Khan, G.S.; Hussain, H.; Ozkan, S.A. Highly sensitive and selective electrochemical sensor for the trace level detection of mercury and cadmium. Electrochim. Acta 2017, 258, 1397-1403. [CrossRef]

92. Ganjali, M.R.; Rahmani, A.R.; Shokoohi, R.; Farmany, A.; Khazaei, M. A Highly Sensitive and Selective Electrochemical Mercury (II) Sensor Based on Nanoparticles of $\mathrm{Hg}$ (II)-imprinted Polymer and Graphitic Carbon Nitride (gC 3N4). Int. J. Electrochem. Sci. 2019, 14, 6420-6430. [CrossRef]

93. Devi, N.R.; Sasidharan, M.; Sundramoorthy, A.K. Gold Nanoparticles-Thiol-Functionalized Reduced Graphene Oxide Coated Electrochemical Sensor System for Selective Detection of Mercury Ion. J. Electrochem. Soc. 2018, 165, B3046-B3053. [CrossRef]

94. Sánchez-Calvo, A.; Fernández-Abedul, M.T.; Blanco-López, M.C.; Costa-García, A. Paper-based electrochemical transducer modified with nanomaterials for mercury determination in environmental waters. Sens. Actuators B Chem. 2019, 290, 87-92. [CrossRef] 
95. Vu, T.D.; Khac Duy, P.; Bui, H.T.; Han, S.-H.; Chung, H. Reduced graphene oxide-Nickel sulfide (NiS) composited on mechanical pencil lead as a versatile and cost-effective sensor for electrochemical measurements of bisphenol A and mercury (II). Sens. Actuators B Chem. 2019, 281, 320-325. [CrossRef]

96. Sakthinathan, S.; Tamizhdurai, P.; Ramesh, A.; Chiu, T.-W.; Mangesh, V.L.; Veerarajan, S.; Shanthi, K. Platinum incorporated mordenite zeolite modified glassy carbon electrode used for selective electrochemical detection of mercury ions. Microporous Mesoporous Mater. 2020, 292, 109770. [CrossRef]

97. Wang, W.; Bao, N.; Yuan, W.; Si, N.; Bai, H.; Li, H.; Zhang, Q. Simultaneous determination of lead, arsenic, and mercury in cosmetics using a plastic based disposable electrochemical sensor. Microchem. J. 2019, 148, 240-247. [CrossRef]

98. Li, Y.; Xie, J.-F.; Chang, C.-C.; Wang, C.-M.; Tu, H.-L. Highly Sensitive Detection of Mercury Ion Using Zincophosphite Framework Nanoparticle-Polyaniline Composites. ACS Appl. Nano Mater. 2020. [CrossRef]

(C) 2020 by the authors. Licensee MDPI, Basel, Switzerland. This article is an open access article distributed under the terms and conditions of the Creative Commons Attribution (CC BY) license (http://creativecommons.org/licenses/by/4.0/). 